\title{
La intangibilidad cuantitativa de la legítima en el código civil chileno. Una mirada desde el derecho sudamericano*
}

\section{Manuel Barría Paredes ${ }^{* *}$}

Resumen. El objetivo del presente trabajo es el análisis de los diversos mecanismos de protección de las legítimas en el código civil chileno y su comparación con los medios de protección de esta misma asignación en el derecho sudamericano, con el objeto de determinar si son similares o distintos (y en tal caso si las diferencias son o no sustanciales), o si tienen otras formas de protección no conocidas en nuestro sistema sucesorio.

Palabras clave: derecho sucesorio, legítima, protección de la legítima, derecho sudamericano.

\section{The Quantitative Intangibility of the Reserved Part in Chilean Civil Code: Latin American Law Perspective}

Авsтract. The objective of this study is to analyze the various mechanisms of protection of the reserved part in the Chilean Civil Code, and compare them with

* Fecha de recepción: 20 de octubre de 20I7. Fecha de aceptación: 30 de abril de 2018.

Para citar el artículo: Barría Paredes, M., "La intangibilidad cuantitativa de la legítima en el código civil chileno. Una mirada desde el derecho sudamericano", Revista de Derecho Privado, Universidad Externado de Colombia, n. ${ }^{\circ}$ 35, julio-diciembre de 2018 , I29-г6r. Dor: https://doi. org/I0.1860I/or $234366 . n 35.06$

Este artículo se enmarca dentro del Proyecto Fondecyt Iniciación n. ${ }^{\circ}$ i I I 50656, del cual el autor es investigador responsable. Agradezco a Fondecyt por el financiamiento de este proyecto de investigación. Agradezco también el apoyo de los ayudantes de este proyecto, los alumnos de la Carrera de Derecho de la Universidad de Concepción, Chile, Michelle Inzunza, Laura Kuncar, Víctor Mendoza y Diego Torres.

** Doctor en Derecho, Pontificia Universidad Católica de Chile. Profesor de Derecho Civil, Universidad de Concepción, Concepción, Chile. Contacto: mbarria@udec.cl 
the different protection mechanisms of this share of the inheritance in South American Law, in order to determinate if they are similar or different (and in that case, if the differences are substantial or not), or if they has other ways of protection unknown in our succession system.

KeYwords: Succession Law, Reserved part (minimum share), protection of the reserved part, Latin American Law.

Sumario. Introducción. i. La legítima en el derecho chileno. Legítima como derecho y legítima como contenido. II. El principio de intangibilidad de la legítima. III. El principio de intangibilidad cuantitativa de la legítima. Iv. La colación o formación del primer acervo imaginario. v. La formación del segundo acervo imaginario. A. En cuanto a la naturaleza de la acción. B. Respecto de la forma como opera la restitución. vi. La legítima no puede ser objeto de modalidades o gravámenes. viI. La prohibición de celebrar pactos sobre sucesión futura. VIII. La acción de reforma de testamento. Ix. La preterición. Conclusiones. Referencias.

\section{Introducción}

El sistema sucesorio chileno, en cuanto a la libertad de disposición de los bienes del causante mediante testamento, adoptó por un sistema de freno o de límite a dicha facultad, estableciendo las asignaciones forzosas indicadas en el artículo i 67 c.c. chileno ${ }^{\mathrm{I}}$. Bello, por lo tanto, se alejó tanto del sistema de absoluto freno o delación forzosa de la herencia ${ }^{2}$, como también de un sistema de absoluta libertad de testar ${ }^{3}$, ambos como los dos polos opuestos de un sistema sucesorio, no obstante que en las fuentes históricas del código civil chileno el codificador era partidario de este último sistema ${ }^{4}$.

I En adelante, cualquier referencia que se haga a un artículo, sin especificar la fuente, se entiende realizada al código civil chileno.

2 Que en todo caso hoy no se conocen en el derecho comparado.

3 En el sistema de libertad de testar, el causante es libre y soberano para disponer a través del testamento de todo o de parte de sus bienes, a favor de la persona que quiera y haciendo la distribución que desee entre ellos. Hoy día no hay un sistema de absoluta libertad de testar, porque incluso en los países que tienen ese principio se ha ido limitando esta facultad de disposición mediante el derecho de alimentos. Una descripción de este sistema para algunos países de Latinoamérica se puede apreciar en Barría Paredes, M., "Panorama normativo de los sistemas sucesorios en Latinoamérica”, en Barría, M.; B. Caprile, J. L. Díez, C. Domínguez, C. Pizarro y M. Tapia (coords.), Estudios de derecho privado. Homenaje al profesor Ramón Domínguez Águila, Santiago, Thomson Reuters, 2015 , I 38 -1 42.

4 Así se puede apreciar en la revisión de las Obras Completas de Bello, en una nota al proyecto de I853, en el que señalaba: "Las legítimas no son conocidas en la mayor parte de Gran Bretaña y de los Estados Unidos de América; y tal vez no hay países donde sean más afectuosas y tiernas las relaciones de familia, más santo el hogar doméstico, más respetados los padres, o procurada con más ansia la educación y establecimiento de los hijos”. Y más adelante criticaba el sistema de legítimas, 
Así entonces, en Chile se adoptó un sistema mixto, pues la libertad de testar se encuentra limitada por las asignaciones forzosas, que de acuerdo al artículo I 67 son:

I. Los alimentos que se deben por ley a ciertas personas;

2. Las legítimas;

3. La cuarta de mejoras en la sucesión de los descendientes, de los ascendientes y del cónyuge 5 .

Este es el mismo esquema que adoptaron en forma íntegra Colombia ${ }^{6} \mathrm{y}$ Ecuador ${ }^{7}$, tal como lo indica Guzmán Brito ${ }^{8}$. Pero este sistema fue propio de Bello, porque se puede apreciar que en el resto de Latinoamérica algunos países adoptaron un sistema similar al del código civil español (que contempla una parte de libre disposición y la legítima; por su parte, la legítima se divide en dos, esto es, la legítima propiamente tal y la mejora) ${ }^{9}$, o bien un sistema de legítimas puro, en donde existe una parte de libre disposición y otra de legítimas ${ }^{\mathrm{IO}}$,

indicando: "En el establecimiento de legítimas, la filosofía no parece estar de acuerdo con la legislación. Aquel antiguo principio de los romanos: 'Pater familias uti legassit [...] ita jus esto', sería la regla que propondríamos si no fuese preciso transigir con las preocupaciones". Finalmente señalaba: "El establecimiento de legítimas, no sólo es vicioso porque es innecesario (pues no deben multiplicarse las leyes sin necesidad), sino porque, complicando las particiones, suscitando rencillas y pleitos en el seno de las familias, retardando el goce de los bienes hereditarios, ocasiona a los herederos un daño muy superior al beneficio que pudiera alguna vez acarrearles". Lo anterior en BeLLo LóPEz, A., Código civil de la República de Chile, Caracas, Ministerio de Educación, I955, I87-I88.

5 El código civil chileno, en su versión original, contemplaba también como asignación forzosa la llamada "Porción Conyugal", pero ella fue suprimida de nuestro sistema sucesorio por medio de la Ley n. ${ }^{\circ}$ 19.585, de 26 de octubre de 1998. Pero hoy también hay que agregar como asignatario de legítimas y de la cuarta de mejoras al conviviente civil, luego que en Chile entrara en vigencia la Ley n. ${ }^{\circ} 20.830$, que crea el acuerdo de unión civil y que confirió al conviviente civil los mismos derechos hereditarios que al cónyuge sobreviviente, en sus artículos i6 a I9.

6 Así, el código civil de Colombia establece en el artículo i 226 que las asignaciones forzosas son: I. ${ }^{\circ}$ Los alimentos que se deben por ley a ciertas personas; $2 .{ }^{\circ}$ La porción conyugal; $3{ }^{\circ}$ Las legítimas; $4{ }^{\circ}$ La cuarta de mejoras en la sucesión de los descendientes legítimos.

7 El código civil de Ecuador en el artículo i 2 i6 define las asignaciones forzosas y las enumera, pero a diferencia del código chileno no se contempla al derecho de alimentos como asignación forzosa, aunque sí el derecho a la porción conyugal (que tiene carácter alimenticio), las legítimas y la cuarta de mejoras.

8 Sobre la historia de la codificación en Colombia y Ecuador, y la adopción del código civil chileno, cfr. Guzmán Brito, A., La codificación civil en Iberoamérica. Siglos XIX y XX, Santiago, Jurídica de Chile, 2000, 374-395.

9 Así, Puerto Rico sigue en forma íntegra al código civil español en esta materia, lo que se puede apreciar en el artículo 737 que establece: "Constituyen la legítima de los hijos y descendientes legítimos las dos terceras partes del haber hereditario del padre y de la madre. Sin embargo, podrán éstos disponer de una parte de las dos que forman la legítima, para aplicarla como mejora a sus hijos y descendientes legítimos o naturales legalmente reconocidos".

Io Dentro de los países latinoamericanos que siguieron este sistema se puede encontrar a Brasil, Argentina, Bolivia, Uruguay, Paraguay y Perú. Así por ejemplo, el Código Civil y Comercial de la Nación de Argentina, establece en el artículo 2445 la llamada "Porción legítima", indicando: "La porción legítima de los descendientes es de dos tercios, la de los ascendientes de un medio y la del cónyuge de un medio". 
sin que se conozca la mejora, de origen netamente español y que no fue conocida en el derecho romano ${ }^{\mathrm{II}}$. Hay que destacar también el nuevo Código Civil y Comercial de la Nación Argentina, que estableció una mejora para personas que padezcan de alguna discapacidad. Así, el artículo 2448 indica:

El causante puede disponer, por el medio que estime conveniente, incluso mediante un fideicomiso, además de la porción disponible, de un tercio de las porciones legítimas para aplicarlas como mejora estricta a descendientes o ascendientes con discapacidad. A estos efectos, se considera persona con discapacidad, a toda persona que padece una alteración funcional permanente o prolongada, física o mental, que en relación a su edad y medio social implica desventajas considerables para su integración familiar, social, educacional o laboral.

Pero lo cierto es que, de cualquier modo que se analicen estos diversos sistemas, el denominador común para todos ellos es la legítima. Luego, es la ley quien les reconoce un derecho a ciertos asignatarios, que la ley llama "legitimarios", y es a ellos entonces a quienes el legislador debe proteger, con el objeto de que no se vean vulnerados sus derechos en la sucesión, estableciéndose ciertos medios para cautelarlos.

El objetivo del presente trabajo, entonces, será analizar los diversos mecanismos de protección de las legítimas en el código civil chileno y compararlos con los medios de protección de esta misma asignación en el derecho sudamericano, con el objeto de determinar si son similares o distintos (siendo o no sustanciales), o si tienen otras formas de protección no conocidas en nuestro sistema sucesorio.

\section{La legítima en el derecho chileno. Legítima como derecho y legítima como contenido}

El código civil definió la legítima en el artículo i I8 I, indicando: "Legítima es aquella cuota de los bienes de un difunto que la ley asigna a ciertas personas llamadas legitimarios". Si bien no se indica expresamente por la ley, es posible analizar la legítima desde dos puntos de vista, esto es, desde el punto de vista del derecho que tienen los legitimarios sobre esa asignación, o bien desde el punto de vista del contenido de dicha legítima. Así entonces, se ha realizado una distinción entre la legítima como derecho (llamada también legítima formal) y la legítima como contenido (llamada también legítima material).

Así, Albaladejo señalaba: "La mejora es una institución típicamente castellana, que, introducida por Chindasvinto, aparece acogida en el Liber Iudiciorum, en su versión romance, el Fuero Juzgo, y, asimismo, en diversos fueros municipales, habiendo sido regulada detalladamente, con gran abundancia de preceptos, una docena de leyes, en las de Toro. Cuerpo jurídico, éste, que es el que, en nuestro Derecho histórico más atención, con diferencia respecto de cualquier otro, le dedicó". Albaladejo García, M., La mejora, Madrid, Servicio de Estudios del Colegio de Registradores, $2003, \mathrm{I} 8$. 
Domínguez Benavente y Domínguez Águila indican al respecto: "Si consideramos entonces la legítima como derecho (legítima formal), puede afirmarse que la ley asegura al legitimario que recibirá una cuota de la herencia. Y determina su quantum (art. I I 84). Por ello el legitimario es heredero. La legítima es, pues, desde ese punto de vista, una parte de la herencia" ${ }^{22}$.

En Chile, la legítima es variable, según estemos en presencia de la legítima rigorosa $^{\mathrm{I} 3}$ o de la legítima efectiva. La legítima rigorosa es la parte que a cada legitimario le corresponde en la mitad legitimaria, que según el artículo i i 84 se determina deduciendo de la mitad de los bienes del causante las bajas generales de la herencia indicadas en el artículo 959 y haciendo las agregaciones que se indican en los artículos siguientes, esto es, haciendo las acumulaciones que ahí se señalan y que en general se refieren a las donaciones realizadas por el causante a otro legitimario o a un tercero. Realizadas entonces esas operaciones, se determinará la legítima rigorosa de cada legitimario, distribuyéndose entre ellos de acuerdo a las reglas de la sucesión intestada. La misma regla se encuentra en el código civil de Colombia ${ }^{14}$, y lo propio ocurre en el código civil ecuatoriano ${ }^{15}$.

Por su parte, el artículo i igi se refiere a la legítima efectiva, indicando que "[a]crece a las legítimas rigorosas toda aquella porción de los bienes de que el testador ha podido disponer a título de mejoras, o con absoluta libertad, y no ha dispuesto, o si lo ha hecho, ha quedado sin efecto la disposición. Aumentadas así las legítimas rigorosas se llaman legítimas efectivas"; regla que también es posible advertir en el código civil de $\operatorname{Colombia}^{16} \mathrm{y}$ en el código civil de

i 2 Domínguez Benavente, R. y R. Domínguez Águila, Derecho sucesorio, t. iI, 3· ${ }^{a}$ ed., Santiago, Jurídica de Chile, 20 I I, 923.

I 3 En cuanto a la nomenclatura utilizada, el código civil chileno denomina a esa legítima como "rigorosa". La aclaración, por cuanto otros códigos civiles o la doctrina en algunos casos la llaman "legítima rigurosa". Es el caso del derecho civil colombiano, como tendremos la oportunidad de apreciar.

I4 Así, el artículo i 242 c.c. de Colombia indica: "La mitad de los bienes, previas las deducciones de que habla el artículo ror6 y las agregaciones indicadas en los artículos I 243 a I 245 se dividen por cabezas o estirpes entre los respectivos legitimarios, según el orden y reglas de la sucesión intestada; lo que cupiere a cada uno en esta división es su legítima rigurosa". Sobre la legítima rigorosa y la legítima efectiva en el derecho civil colombiano, cfr. Vélez, F., Estudio sobre el derecho civil colombiano, t. Iv, París, Imprenta París-América, I929, 4I8-427; Suárez Franco, R., Derecho de sucesiones, 6. ${ }^{\mathrm{a}}$ ed., Bogotá, Temis, 20 I 5, 329-33 I; Aguado Montaño, E., Derecho de sucesiones, Bogotá, Leyer, 2000, I96-i 99; Ramírez Fuentes, R., Las sucesiones, Bogotá, Colección Pequeño Foro, I983, I65-i66.

I 5 La regla del artículo 207 c.c. de Ecuador reproduce íntegramente el artículo I 84 inciso I. ${ }^{\circ}$ c.c. chileno, al establecer: "La mitad de los bienes, previas las deducciones y agregaciones indicadas en el Art. I O० I y las que enseguida se expresan, se dividirá por cabezas o estirpes entre los respectivos legitimarios, según las reglas de la sucesión intestada. Lo que cupiere a cada uno en esa división será su legítima rigorosa".

I6 Se refiere a la legítima efectiva el artículo s 249, que indica: "Acrece a las legítimas rigurosas toda aquella porción de los bienes de que el testador ha podido disponer a título de mejoras, o con absoluta libertad, y no ha dispuesto y si lo ha hecho ha quedado sin efecto la disposición. Aumentadas así las legítimas rigurosas se llaman legítimas efectivas”. 
Ecuador ${ }^{17}$. Por lo tanto, puede ocurrir que la legítima no necesariamente sea equivalente a la mitad de la herencia, pudiendo llegar a tres cuartas partes de la herencia o incluso a la herencia completa, en las hipótesis descritas en la referida norma. Pero, sea que estemos en presencia de la legítima rigorosa o de la legítima efectiva, el legitimario tiene derecho sobre ella, esto es, tiene derecho a la legítima formal.

Por otra parte, se debe considerar también la legítima desde el punto de vista de su contenido, y así entonces se reconoce a la llamada "legítima material", que no es otra cosa que determinar cómo se integra la legítima. Como indican Domínguez Benavente y Domínguez Águila:

La integración de la legítima puede hacerla el causante en variadas formas que la ley entrega a su libre arbitrio: bien mediante la simple institución de heredero en la cuota legal (para lo cual le basta disponer que instituye al sucesor en su legítima), o bien mediante legados que se imputen a su legítima. Incluso puede hacer donaciones entre vivos al legitimario con cargo a su legítima (arts. i i 85, i I93, I I98, i 200). Puede indicar en su testamento los bienes que han de componer la legítima (arts. I I 97 y I I98) ${ }^{18}$.

Por lo tanto, desde este punto de vista, hay una mayor libertad para el causante en orden a atribuir la legítima de diversas maneras.

Pero, ya sea que se considere a la legítima desde el punto de vista formal o bien desde el material, dicha asignación forzosa es objeto de protección, la cual se manifiesta a través del principio de intangibilidad de la legítima.

\section{El principio de intangibilidad de la legítima}

Lo indicado en el acápite anterior, en el sentido de que la legítima puede ser analizada tanto en cuanto derecho como también en razón de su contenido, implica considerar que la legítima es "intangible". En esa línea, si se afirma que los legitimarios tienen derecho a su legítima desde el punto de vista del quantum, significa que dicha legítima debe ser intangible desde un punto de vista "cuantitativo".

Por otra parte, si se entiende que la legítima también hay que analizarla desde el punto de vista de la forma en que se concreta, esto es, desde el punto de vista de su contenido, la misma debe ser satisfecha con bienes que forman

I 7 Así lo establece el artículo I 2 I 4 c.c. ecuatoriano, al señalar: "Acrece a las legítimas rigorosas la porción de los bienes de que el testador ha podido disponer a título de mejoras, o con absoluta libertad, y no ha dispuesto, o si lo ha hecho, ha quedado sin efecto la disposición.

"Aumentadas así las legítimas rigorosas, se llaman legítimas efectivas".

Domínguez y Domínguez, Derecho sucesorio, cit., 925. 
parte de la herencia. Por ello la legítima es intangible desde un punto de vista "cualitativo". En resumen, y tal como indica Capozzi:

... se distinguen dos formas de intangibilidad: cuantitativa y cualitativa. La primera significa que el legitimario tiene el derecho a obtener un valor equivalente al de su cuota, pero no un derecho sobre cada bien. La segunda significa que el legitimario tiene derecho a obtener su cuota en especie, esto es, tiene el derecho a obtener una cuota formada, en proporción a la cuantía de ésta, por una parte de cada uno de los bienes hereditarios ${ }^{19}$.

El código civil no definió ni se refirió en forma expresa a la intangibilidad de la legítima ${ }^{20}$, pero su presencia se desprende de diversas disposiciones. $\mathrm{Y}$ es en virtud de este principio que el legislador ha establecido distintos mecanismos de protección a las asignaciones forzosas, y en especial a la legítima. Dichas formas de protección se encontrarán seguramente en las reglas de asignaciones forzosas que establece el código civil, pero también hay otras maneras indirectas de proteger. Así por ejemplo, se puede proteger a través de la declaración de interdicción por demencia o disipación del causante, con el objeto de evitar que dicho causante se desprenda de su patrimonio y así disminuya los futuros derechos hereditarios de los legitimarios; del mecanismo de insinuación de las donaciones irrevocables, por la cual el causante requiere de autorización del juez competente para realizar la referida donación en ciertos casos, que también tiene por objeto evitar que disminuya el patrimonio del causante, perjudicando el eventual derecho del legitimario; de la limitación de las donaciones por causa de matrimonio, que podrían lesionar los derechos de los hijos como legitimarios ${ }^{2 \mathrm{I}}$.

Otra forma de proteger a los legitimarios frente a fraudes que pudiera cometer el causante para perjudicar sus derechos como legitimarios está dada por la posibilidad de atacar los contratos simulados celebrados por el causante con otro legitimario o con un tercero, a través del ejercicio de la llamada "acción de simulación”, y especialmente mediante el ejercicio de la acción de nulidad

I9 Capozzi, G., Successioni e donazioni, t. I, 4. ${ }^{\text {a }}$ ed., Milano, Giuffré, 20 I 5, 467.

20 En algunos códigos civiles, especialmente del siglo $\mathrm{xx}$, se ha conceptualizado este principio. Es lo que ocurre con el código civil italiano, que en su artículo 457 inciso $3 .^{\circ}$ indica: "Las disposiciones testamentarias no pueden perjudicar los derechos que las leyes reservan a los legitimarios". Ello aunque se desarrolla el principio en los artículos 549 y siguientes del mismo código. Sobre el principio de intangibilidad de la legítima en el derecho italiano cfr. Ottani Sconza, V., "I legittimari", en Balestra, L. y M. Di Marzio (coords.), Successioni e donazioni, Padova, Cedam, 2014, 704-709; Campagnolo, R., Le successioni mortis causa, Torino, Utet, 201 I, 365379; Balestra, L.; M. Di Marzio, A. Gianola, V. Lenoci y S. Matteini Chiari, "Successioni e donazioni", en Cendon, P. (dir.), Trattato di diritto civile, Milano, Giuffré, 201 5, 224-2 27.

2 I Respecto de los mecanismos de protección de las asignaciones forzosas en el código civil chileno, cfr. Elorriaga De Bonis, F., Derecho sucesorio, 3. ${ }^{a}$ ed., Santiago, Thomson Reuters, 20 5 , 440-44I. 
absoluta por los legitimarios, el cual tendrá como objetivo restablecer el patrimonio del causante, con el objeto de concurrir y de ejercer sus derechos en la herencia del de cujus.

Pero para los efectos de este trabajo, solo nos referiremos a los mecanismos de protección de la legítima que se otorgan en el código civil en materia de asignaciones forzosas, a la luz del principio de intangibilidad, analizándola en esta oportunidad solo desde el punto de vista cuantitativo, sin perjuicio de que en ciertos casos los mecanismos de protección también hay que vincularlos con el principio de intangibilidad cualitativa ${ }^{22}$, como tendremos la oportunidad de revisar.

\section{El principio de intangibilidad cuantitativa de la legítima}

Como se indicó, se entiende que la legítima es intangible en cuanto constituye un derecho a ella, es decir, el legitimario tiene derecho a su cuota en la herencia, con el fin de que ella no sea afectada. Y es en ese sentido que el legislador otorga al legitimario una serie de mecanismos para proteger ese derecho en la legítima. A continuación desarrollaremos los más relevantes. Se analizará su regulación en el derecho chileno, y en seguida su recepción en el derecho latinoamericano, en el sentido de determinar si tal medio de protección se acoge o no en tales sistemas, y en caso de respuesta afirmativa, si se concibe de la misma forma o no que en el derecho chileno.

\section{La colación o formación del primer acervo imaginario}

Se establece en el artículo i 85 c.c., el cual dispone:

Para computar las cuartas de que habla el artículo precedente, se acumularán imaginariamente al acervo líquido todas las donaciones revocables e irrevocables, hechas en razón de legítimas o de mejoras, según el estado en que se hayan encontrado las cosas donadas al tiempo de la entrega, pero cuidando de actualizar prudencialmente su valor a la época de la apertura de la sucesión.

Luego, mediante este mecanismo se protege al legitimario frente a las donaciones que haya realizado el causante a otro legitimario y que pudieran afectar su derecho a la legítima. En ese sentido, lo que se persigue es recomponer valorativamente el patrimonio del causante, agregando en forma imaginaria las donaciones que se hicieron a otro legitimario, a través de las operaciones del artículo i 84 c.c. Realizado aquello será necesario imputar a la legítima o mejora en su

22 Sobre el principio de intangibilidad cualitativa de la legítima, cfr. Real Pérez, A., Intangibilidad cualitativa de la legítima, Madrid, Civitas, I988, I3-I47. 
caso, la donación que el causante realizó a otro legitimario, con el objeto de no afectar la legítima del o los legitimarios, desde un punto de vista cuantitativo ${ }^{23}$, lo que no es otra cosa que una aplicación del principio de igualdad que debe existir entre todos ellos ${ }^{24}$.

Estas operaciones no son desconocidas en el derecho comparado. Las mismas reglas se contemplan en las legislaciones que siguieron el código civil chileno, como Colombia y Ecuador. Así, en el caso del derecho colombiano tiene aplicación lo dispuesto en el artículo i 243 c.c., el cual indica: "Para computar las cuartas de que habla el artículo precedente, se acumularán imaginariamente al acervo líquido todas las donaciones revocables e irrevocables, hechas en razón de legítimas o de mejoras, según el valor que hayan tenido las cosas donadas al tiempo de la entrega, y las deducciones que, según el artículo I 234, se hagan a la porción conyugal” ${ }^{25}$. Por su parte, el artículo r 208 c.c. de Ecuador dispone: "Para computar las cuartas de que habla el artículo precedente, se acumularán imaginariamente al acervo líquido todas las donaciones revocables o irrevocables, hechas en razón de legítimas o de mejoras, según el valor que hayan tenido las cosas donadas al tiempo de la entrega, y las deducciones que, según el artículo I I99, se hagan a la porción conyugal”26. Luego, tanto en Colombia como en Ecuador se ha seguido íntegramente en esta materia al código civil de Chile.

Otros países también tienen el sistema de colación, especialmente aquellos que siguieron el código civil italiano de 1942 , que regula en forma separada y

23 Sobre la colación o formación del primer acervo imaginario, cfr. BAZÁn Dávila, R., "De la colación”, memoria de prueba para optar al grado de Licenciado en Ciencias Jurídicas, Santiago, Universidad de Chile, i946, 5-97; Domínguez y Domínguez, Derecho, cit., 985-io25; Ramos Pazos, R., Sucesión por causa de muerte, Santiago, Jurídica de Chile, 2008, I 24-I 25; Somarriva Undurraga, M., Derecho sucesorio, $7 .^{a}$ ed. (versión de R. Abeliuk), Santiago, Jurídica de Chile, 2007, 392-402; Elorriaga, Derecho, cit., 495-5 I I.

24 Peñallillo Arévalo, D., "El principio de igualdad en el derecho sucesorio", Revista de Derecho Universidad de Concepción, n. ${ }^{\circ}$ I 43, I968, 62-63.

25 Sobre la formación del primer acervo imaginario en Colombia, Ramírez ha indicado: "El legitimario que estime afectado su derecho, por razón de anticipos hechos por el causante a otro legitimario por la vía de las donaciones, tendrá derecho a pedir que su valor se colacione, es decir se tenga en cuenta imaginariamente para computar las legítimas. Se agregarán no las cosas, sino el valor de éstas; y cumplida la colación a que hubiere lugar, para tomar como existente aquello que ya salió del patrimonio puesto que fue donado, los cálculos para liquidar las asignaciones serán reales y positivos para dar a cada legitimario lo que le corresponde. Colacionar es, entonces, sumar el valor de las cosas donadas al acervo líquido real para reconstituir, en su integridad, el acervo partible; el valor será el 'que hayan tenido las cosas donadas al tiempo de la entrega' (artículo I 243), o sea que se trata de incorporar al patrimonio las donaciones irrevocables pues solo en las irrevocables las cosas salen del patrimonio del causante y es preciso traerlas a cuenta o a colación”. Ramírez, Las sucesiones, cit., i 72. Cfr. también, Velásquez Londoño, R., Derecho de berencia, Medellín, Librería Señal Editora, I988, 220-228.

26 Referencias respecto la formación del primer acervo imaginario en Ecuador se pueden encontrar en Bossano, G., Manual de derecho sucesorio, 2. ${ }^{\mathrm{a}}$ parte, Quito, Voluntad, I983, 50-5 I; Orbe, H., Derecho de sucesión, t. II, Quito, Imprenta Editorial, I977, I77-187. 
expresa esta institución. Siguieron dicho código Venezuela ${ }^{27}$ y, especialmente, Bolivia. Como indica Guzmán Brito: "En general, el modelo principal seguido por el nuevo cuerpo legal boliviano fue precisamente el código italiano de I942, beneficiándose de todas sus novedades legislativas" ${ }^{28}$. Es así como el código boliviano indica en el artículo I 254: "Toda donación hecha a heredero forzoso que concurra a la sucesión del donante importa anticipo de su porción hereditaria,

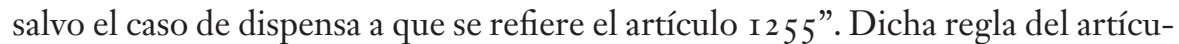
lo I 255 expresa: "El heredero que concurra a la sucesión con otros que también lo sean, debe colacionar a la masa hereditaria todo lo que ha recibido del difunto por donación, directa o indirectamente, excepto cuando el donante o testador hubiese dispuesto otra cosa. El heredero dispensado de la colación no puede retener lo donado más que hasta la concurrencia de la porción disponible”. Estas reglas no se encuentran en materia de legítimas, sino que constituyen un tópico que se analiza en la partición de la comunidad hereditaria, de la misma manera como lo hace el código civil italiano, en sus artículos 737 y siguientes ${ }^{29}$.

En el nuevo Código Civil y Comercial de Argentina se estableció también la obligación de colacionar para los herederos, regla que también se halla presente en materia de partición. Así, el artículo 2385 dispone: "Personas obligadas a colacionar. Los descendientes del causante y el cónyuge supérstite que concurren a la sucesión intestada deben colacionar a la masa hereditaria el valor de los bienes que les fueron donados por el causante, excepto dispensa o cláusula de mejora expresa en el acto de la donación o en testamento. Dicho valor se determina a la época de la donación”. El antiguo código argentino mantenía el mismo principio, en cuanto al momento y forma de colacionar, regulándose junto con las reglas de partición de bienes ${ }^{3 \circ}$. Lo mismo ocurre en otras

27 En el código civil de Venezuela se regula la colación y la imputación en sus artículos ro83 y siguientes, después de la partición de bienes, tal como el código civil italiano. Así, el artículo Io8 3 dispone: "El hijo o descendiente que entre en la sucesión, aunque sea a beneficio de inventario, junto con sus hermanos o hermanas, o los descendientes de unos u otras, deberá traer a colación todo cuanto haya recibido del de cujus por donación, directa o indirectamente, excepto el caso en que el donante haya dispuesto otra cosa".

28 Guzmán, La codificación, cit., 524.

29 Sobre el sistema de colación en el derecho italiano, cfr. Colangeli, D., "La collazione", en Balestra y Di Marzio, Successioni e donazioni, cit., I495-I 573; Campagnolo, Le successioni, cit., 637-65 I.

30 Sobre la colación en derecho civil argentino, cfr. Maffía, J., Tratado de las sucesiones, t. I, 2. ${ }^{\text {a }}$ ed., Buenos Aires, Abeledo Perrot, 2010, 569-62 2; Borda, G., Manual de sucesiones, I4. ${ }^{2}$ ed., Buenos Aires, LexisNexis y Abeledo Perrot, 2004, 208-228; Pérez Lasala, J. L., Curso de derecho sucesorio, 2. ${ }^{a}$ ed., Buenos Aires, LexisNexis, 2007, 319-342. 
legislaciones sudamericanas, como las de Paraguay ${ }^{3}$, Uruguay ${ }^{32}$, Perú ${ }^{33}$ y Brasil34.

Por lo tanto, en materia de colación por donaciones que hizo el causante a un legitimario, se encuentran algunas diferencias entre los países que siguieron el código civil chileno y los otros países sudamericanos, pues en estos últimos dicha operación se vincula a la partición de bienes, la que está de cierta forma limitada en el sistema jurídico chileno, por cuanto cualquier cuestión que se suscite entre los legitimarios (como podría ser el caso de donaciones del causante a un legitimario que perjudiquen el derecho de los demás) debe ser resuelta con anterioridad a la partición y no resolverse en la partición misma. Así por ejemplo, en el caso de que la partición de bienes se quiera hacer de común acuerdo, el artículo I 325 c.c. ordena perentoriamente: "Los coasignatarios podrán hacer la partición por sí mismos si todos concurren al acto, aunque entre ellos haya personas que no tengan la libre disposición de sus bienes, siempre que no se presenten cuestiones que resolver y todos estén de acuerdo sobre la manera de hacer la partición". Por su parte, en el caso de que la partición la haga un juez partidor, el artículo I330 dispone expresamente: "Antes de proceder a la partición, se decidirán por la justicia ordinaria las controversias sobre derechos a la sucesión por testamento o abintestato, desheredamiento, incapacidad o indig-

3 I Que se refiere a la colación en los artículos 2544 a 2552. Sobre la protección de la legítima a través de la colación en el derecho paraguayo cfr. KöHn Gallardo, M.A., La legítima hereditaria, Asunción, Intercontinental, 2008, 70-93.

32 El código civil uruguayo reguló en forma conjunta la colación y la partición, en los artículos I I o y siguientes. Así, el artículo I I o indica: "La colación consiste en la agregación al cúmulo de la herencia, que hacen los herederos forzosos, de los bienes que recibieron del difunto cuando vivía y que deben serles imputados en su respectiva legítima. La colación sólo se debe por el heredero forzoso a su coheredero". Cfr. Irureta Goyena, J., Curso de sucesiones, t. v, Montevideo, Centro de Estudiantes de Derecho, I966, 207-286; MARIÑo López, A., Código civil de la República Oriental del Uruguay. Comentado, anotado y concordado, Montevideo, La ley, 20o9, 570-576.

33 El código civil del Perú del año i 984 reguló la colación justo antes de la partición de bienes, en los artículos 83 I y siguientes. Así, el artículo 83 I dispone: "Las donaciones u otras liberalidades que, por cualquier título, hayan recibido del causante sus herederos forzosos, se considerarán como anticipo de herencia para el efecto de colacionarse, salvo dispensa de aquél”. Sobre la colación en el derecho peruano, cfr. Aguilar Llanos, B., Derecho de sucesiones, Lima, Ediciones Legales, 20Io, 50 I-530; Fernández Arce, C., Manual de derecho sucesorio, Lima, Pontificia Universidad Católica del Perú, 20 I4, 293-3 i i; Ferrero, A., Derecho de sucesiones, 4. a ed., Lima, Cultural Cuzco, i993, 725-774; Taramona Hernández, J. R., Derecho de sucesiones, Lima, Huallaga, I $999,465-478$.

34 Cuyo código civil de 2002 reguló la colación en los artículos 2002 a 2012 , también justo antes de la partición. Sobre la colación en el derecho civil brasileño, cfr. Dias, M. B., Manual das sucessoes, 4. ${ }^{\mathrm{a}}$ ed., Sao Paulo, Revista dos Tribunais, 20 16, 614-636; Elias DE Queiroga, A., Curso de direito civil. Direito das sucessoes, Sao Paulo, Renovar, 2005, 255-263; Gomes, O., Sucessoes, I 2. ${ }^{a}$ ed., Rio de Janeiro, Forense, 2004, 285-293; Lôвo, P., Direito civil. Sucessoes, 2. a ed., Sao Paulo, Saravia, 20 I4, 85-ioo; De Miranda, P., Tratado de direito privado. Parte especial. Direito das sucessoes. t. Lv, Sao Paulo, Revista dos Tribunais, 20 12, 349-425; Ribeiro de Magalhaes, R., Direito das sucessoes no novo código civil brasileiro, 2. ${ }^{\text {a }}$ ed., Sao Paulo, Juarez de Oliveira, 2004, 273-280. 
nidad de los asignatarios". Finalmente, el artículo r 33 I señala: "Las cuestiones sobre la propiedad de objetos en que alguien alegue un derecho exclusivo y que en consecuencia no deban entrar en la masa partible, serán decididas por la justicia ordinaria..." 35 .

\section{La formación del segundo acervo imaginario}

Constituye otra forma de protección de la legítima desde un punto de vista cuantitativo y se calcula en el caso de que el causante haya efectuado donaciones de carácter irrevocable a quienes no tengan la calidad de legitimarios, perjudicando el derecho a la legítima de ellos. El código civil no prohíbe al causante hacer donaciones a los terceros, incluso lo permite y lo regula en los artículos I 386 y siguientes. En tal supuesto, si el causante hace donaciones irrevocables a una persona que no es legitimario y dicha donación no excede de la parte de libre disposición, no se genera problema alguno y por lo tanto no se formará el segundo acervo imaginario. Pero puede ocurrir que estas donaciones irrevocables sean de tal forma excesivas que afecten el derecho de los legitimarios, y es en tal caso que el legislador nuevamente entra a proteger el derecho de esos asignatarios, cautelando y conservando el patrimonio del causante. Es por ello que la ley confiere en Chile a los legitimarios la denominada "acción de inoficiosa donación", cuyo principal objetivo es obtener que los donatarios restituyan el exceso de lo donado, hasta que se reintegre el patrimonio del causante, protegiendo entonces a los legitimarios.

Respecto de esta acción protectora hay dos aspectos que merecen una atención especial, esto es, la naturaleza jurídica de la acción, por una parte, y por otra, la forma en que se produce la restitución de los bienes donados en exceso a los terceros.

\section{A. En cuanto a la naturaleza de la acción}

En Chile no existen dudas de que la acción de inoficiosa donación no constituye una acción de nulidad ${ }^{6}$. Para serlo, tendría que haber existido un vicio en el origen de la donación, lo que acá no ocurre. En este caso la donación del causante al tercero fue de carácter excesivo. Es por ello que el donatario tiene la calidad de dueño de la cosa donada. Luego, los legitimarios perjudicados ejercerán directamente la acción en contra de los donatarios, acción que es personal, patrimonial y prescriptible. Si la acción de inoficiosa donación hubiera sido de nulidad, tendrían que haber emplazado no solo a los donatarios, sino también a los herederos

35 Los mismos principios y reglas pueden encontrarse en los artículos I 345, I347 y I 348 c.c. de Ecuador y en los artículos I 382 , I 387 y I 388 c.c. de Colombia.

36 Domínguez y Domínguez, Derecho, cit., t. II, IO32. 
del causante, pues ambos fueron parte de dicho contrato. Pero además, por el efecto propio de la nulidad, todo lo donado debería haber regresado al patrimonio del causante, lo cual no ocurre en este caso, pues, tal como lo indica el artículo i i 87 , lo que se persigue con la acción es obtener de los donatarios "la restitución de lo excesivamente donado".

En el derecho sudamericano esta acción no es desconocida. Para comenzar, Ecuador ${ }^{37}$ y Colombia ${ }^{38}$, que, como hemos indicado, han seguido en materia sucesoria la obra de Bello, contemplan la formación del segundo acervo imaginario y la acción de inoficiosa donación.

En otros países, esta acción se conoce con otro nombre, y en general se le denomina "acción de reducción de donaciones", "acción de reducción de liberalidades" o simplemente "acción de reducción", la cual no solo se conoce en los países americanos, como veremos, sino que ha sido regulada también en otros sistemas sucesorios, incluso aquellos que emanan del derecho germano, como el derecho civil francés, el cual fue objeto de una importante reforma, por la Ley n. ${ }^{\circ}$ 2006-728, de 23 de junio de 2006, y que tuvo como uno de sus principales objetivos realizar una modificación a esta acción, por ejemplo, estableciendo un pacto sobre sucesión futura que implica una renuncia por parte de los legitimarios al ejercicio de esta acción de reducción, indicada en el artículo 924 del Code39.

La formación del segundo acervo imaginario y la acción de inoficiosa donación se encuentran reguladas en los artículos i 209 y I 2 Io c.c. de Ecuador. Cfr. Bossano, Manual, cit., 52-6o.

$3^{8}$ El código civil colombiano lo regula en los artículos I 244 y I 245. En doctrina, cfr. Álvarez Rico, H., Apuntes de derecho común. Sucesiones, Bogotá, Universidad Católica de Colombia, I986, i 27-I 30; Ramírez, Las sucesiones, cit., I 75-I 77; Cardona Hernández, G., Tratado de sucesiones, Bogotá, Doctrina y Ley, 2004, 26I-265; Carrizosa Pardo, H., Las sucesiones, Bogotá, Lerner, i 977, 423-429; Espinel Blanco, V., Derecho sucesoral, Bogotá, Temis, i984, i 26 - I 2 7; Romero

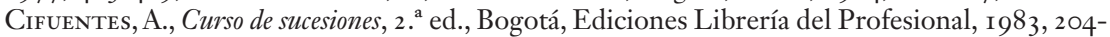
206. Es interesante destacar que sobre estas dos disposiciones del código civil de Colombia en alguna oportunidad se planteó su inconstitucionalidad, indicándose por la parte recurrente que "no hay razón constitucionalmente válida para impedir que las personas que hayan cumplido con sus obligaciones económicas constitucionales o legales como las alimentarias, no puedan distribuir sus bienes en la forma y cuantía que libremente determinen". Y ello implicaba que el causante podía libremente realizar donaciones irrevocables a favor de terceros. Pero la Corte Constitucional de Colombia rechazó tal planteamiento, indicando que dichas disposiciones eran constitucionales, señalando: "Reitera la Corporación que los límites que al derecho de testar libremente ha impuesto el legislador, a través de la institución de las legítimas forzosas, tanto en la sucesión testada como en la intestada, buscan proteger a la familia y se originan en razones de interés público. Tales restricciones son, por lo demás, razonables y constitucionalmente válidas pues se desprenden de la primacía del interés general, representado, en este caso, en la protección de la familia; se explican por razón de la intangibilidad de los derechos económicos que, en favor de sus miembros, ha de producir 'la voluntad responsable' de conformarla, efectos que, como es sabido, se proyectan intemporalmente. No existe pues, por este aspecto, fundamento en las acusaciones formuladas, las que, por tanto, no pueden prosperar". Corte Constitucional de Colombia. Sentencia C-64I de 2000, disponible en: http://www.corteconstitucional.gov.co/ relatoria/2000/C-64I-0o.htm [consultada el 30 de mayo de 20 I 7 ].

39 Esta renuncia a la acción de reducción constituye una novedad, por cuanto en otros sistemas se ha prohibido expresamente la renuncia a dicha acción, como ocurre en el código civil italiano, 
En el resto de Sudamérica, el nuevo código argentino reguló dicha acción en forma expresa en su artículo 24I 7, estableciendo: "El descendiente omitido en la partición por donación o nacido después de realizada ésta, y el que ha recibido un lote de valor inferior al correspondiente a su porción legítima, pueden ejercer la acción de reducción si a la apertura de la sucesión no existen otros bienes del causante suficientes para cubrirla"40. De la misma forma se contempla en otros sistemas, como en el derecho brasileño, específicamente en el artículo i 967, que establece: "Las disposiciones que superen la parte disponible se reducirán a los límites de la misma”. E igual acción se puede encontrar en Paraguay4, Uruguay $^{42}$ y Perú43.

de acuerdo a lo dispuesto en el artículo 557 inciso $2^{\circ}$. La reforma tiene un carácter netamente económico, pues con ello el causante puede dejar una empresa familiar o unidad económica a otro legitimario o a un tercero. Luego, si otro legitimario renuncia a la acción, entonces se consolidará el dominio de dicha empresa o unidad en el donatario beneficiado, no pudiendo el perjudicado ejercer la acción y, como consecuencia de ello, mantener íntegramente la empresa familiar o unidad económica, evitando su extinción. Cfr. Catala, P., "La loi du 23 du juin 2006 et les colonnes du temple", Droit de la famille, n. ${ }^{\circ}$ i I , 2006, 7; Malaurie, P., "La réforme des successions et des libéralités", Répertoire du Notariat Defrénois, n. ${ }^{\circ} 22,2006$, I 73 I.

40 La acción de reducción frente a donaciones inoficiosas no era desconocido en el anterior código civil argentino. En efecto, el anterior artículo I830 establecía: "Repútase donación inoficiosa aquella cuyo valor excede en la parte de que el donante podía disponer". Esa acción podía ejercerse por las personas que indicaba el artículo I $83_{2}$, especialmente en el número I, es decir: "Por los herederos forzosos que existían en la época de la donación; empero si existieren descendientes que tuvieren derecho a ejercer la acción, también competerá el derecho de obtener la reducción a los descendientes nacidos después de la donación".

4I En el código civil de Paraguay se reconoce a las donaciones inoficiosas. Así, su artículo i 226 indica: "Se reputará inoficiosa la donación, cuyo valor excediere de la parte disponible del donante en la fecha de su liberalidad. A este respecto se aplicarán los preceptos sobre la legítima". Por su parte, el artículo I 227 establece: "Si por el avalúo de los bienes del causante resultaren inoficiosa las donaciones realizadas, los herederos necesarios existentes a la fecha de ellas, podrán exigir la reducción hasta quedar cubiertas sus legítimas". Ello se vincula con lo que dispone el artículo 2606, que establece la acción de reducción, al indicar: "Cuando haya que completar la legítima de los herederos forzosos, la acción de reducción podrá ser promovida contra los beneficiarios, a fin de que integren el valor que están obligados a restituir, según las reglas precedentes". Cfr. KöHN, La legítima hereditaria, cit., 93-104.

42 Regulado en el artículo 890 c.c., que dispone: "Fijada la porción legitimaria con arreglo al artículo anterior, para la reducción de las donaciones y legados a la porción disponible, se observará lo siguiente: I. ${ }^{\circ}$ No se llegará a las donaciones mientras pueda cubrirse la porción legitimaria reduciendo o dejando absolutamente sin efecto, si necesario fuere, las disposiciones testamentarias. $2 .^{\circ}$ La reducción de éstas se hará a prorrata sin distinción alguna. Con todo, si el testador quiso que se pagara cierto legado con preferencia a otros, no sufrirá reducción sino después de haberse aplicado éstos por entero al pago de las legítimas. $3{ }^{\circ} \mathrm{Si}$ la disposición consiste en un usufructo o renta vitalicia, cuyo valor se tenga por superior a la parte disponible, los herederos forzosos podrán escoger entre ejecutar la disposición o abandonar la parte disponible. $4 .{ }^{\circ}$ Cuando haya lugar a la reducción de las donaciones, se hará en orden inverso al de su fechas, esto es, principiando por las más recientes; y en lo demás se estará a lo dispuesto en el Libro Cuarto, Título 'De las donaciones'”. Cfr., con aportes de derecho comparado, IruReta, Curso, cit., I67205; Mariño, Código civil, cit., 487-487.

43 Que se encuentra consagrada en el artículo I629, el cual indica: "Nadie puede dar por vía de donación, más de lo que puede disponer por testamento. La donación es inválida en todo lo que 
El código civil italiano, por su parte, la trata expresamente en los artículos 555 y siguientes 44 y, como corolario de ello, en América Latina siguen el mismo principio Bolivia 45 y Venezuela ${ }^{46}$.

\section{B. Respecto de la forma como opera la restitución}

Es justamente en este punto que el principio de intangibilidad no solo debe analizarse desde un punto de vista cuantitativo, sino también desde uno cualitativo. Esto por cuanto, una vez que se ejerce la acción de inoficiosa donación o la acción de reducción, sea cual fuere el sistema revisado, lo cierto es que, al no estar en presencia de una acción de nulidad, no se reintegra todo lo donado, sino solo lo donado en exceso. Y como ya lo hemos indicado, al celebrarse la donación, seguida del correspondiente modo de adquirir mediante tradición, el bien donado pasa al patrimonio del donatario, adquiriendo este el dominio de dicha cosa. Luego, la pregunta que hay que hacer es: ¿debe el donatario restituir lo excesivamente donado con el bien donado, es decir, la restitución debe hacerse in natura? O bien, ¿puede restituir el exceso de lo donado en valor, sin que sea necesario que lo restituido forme parte del bien donado?

$\mathrm{Y}$, justamente en virtud del principio de intangibilidad cualitativa de la legítima, la regla es que la restitución debe hacerse con bienes hereditarios. Ello, además, porque tradicionalmente se ha entendido que la legítima es parte de la

exceda de esta medida. El exceso se regula por el valor que tengan o debían tener los bienes al momento de la muerte del donante". Lo curioso de la norma es que indique que "[1]a donación es inválida en todo lo que se exceda de esta medida", pero en verdad no hay nulidad de la donación, sino que, como es lo común en el derecho comparado, dicha donación está simplemente sujeta a reducción, pues no tiene vicio de origen y además, en principio, el causante puede hacer donaciones. El límite está en el perjuicio que puede producir para los legitimarios. Sobre esta acción en el derecho peruano, cfr. Fernández, Manual, cit., 286-292; Ferrero, Derecho, cit., 754-76o.

44 Campagnolo, Le successioni, cit., 385-423; Lupi, L., "I legittimari”, en Balestra y Di Marzio (coords.), Successioni e donazioni, cit., 728-762.

45 Es así como el artículo ro68 establece: “I. Las disposiciones testamentarias que excedan a la porción disponible que el de cujus puede destinar a liberalidades, están sujetas a reducción hasta el límite de aquélla. II. Igualmente, las donaciones cuyo valor exceda a la porción disponible están sujetas a reducción hasta el límite de aquélla. (Arts. I067, ro7 I del Código Civil). III. Solo después de reducidas las disposiciones testamentarias se deducirán las donaciones". Para el derecho boliviano, en esta materia, cfr. Castellanos Trigo, G., Derecho de sucesiones conforme al código civil boliviano, Sucre, Talleres Gráficos Gaviota del Sur, 2007, I 26 - I 29; Inochea Rojas, J., Manual práctico de derecho sucesorio, Cochabamba, Alexander, 2010, I 56 - 64 .

46 Así, el artículo 888 establece: "Las disposiciones testamentarias que excedan de la porción disponible, se reducirán a dicha porción en la época en que se abra la sucesión”. Por su parte, el artículo 468 dispone: "Las donaciones de toda especie que una persona haya hecho durante los diez últimos años de su vida, por cualquier causa y en favor de cualquiera persona, quedan sujetas a reducción si se reconoce que en la época de la muerte del donador, excedían de la porción de bienes de que pudo disponer el mismo donador”. Cfr. Domínguez Guillén, M. C., Manual de derecho sucesorio, Caracas, Texto, 20 io, 449-468; López Herrera, F., Derecho de sucesiones, t. I, 4. ${ }^{\text {a }}$ ed., Caracas, Universidad Católica Andrés Bello, 2008, 26 I-2 78. 
herencia, esto es, es pars hereditatis y no pars bonorum o pars valoris, y por lo tanto con dichos bienes es que debe hacerse la restitución47. El problema es que en algunas oportunidades no se van a poder restituir bienes hereditarios, pues, como indicamos, el donatario adquirió el dominio de las cosas donadas, y por lo tanto la restitución solo será posible hacerla en valor, por cuanto los legitimarios no se podrán dirigir contra los terceros que adquirieron la cosa donada del donatario, pues la acción de inoficiosa donación es de carácter personal y no real.

Por ello, Domínguez Benavente y Domínguez Águila han indicado: “entendemos que el Código contiene un sistema de reducción en especie y sólo subsidiariamente podría pretenderse una reducción en valor, como en el caso de enajenación de lo donado, ya que siendo la acción de inoficiosidad personal, no puede alcanzar a terceros adquirentes" ${ }^{48}$. Una opinión contraria la encontramos en Rodríguez, quien señala que la restitución debe hacerse en valor, indicando que "[e]l Código Civil es claro en cuanto a que la acción se deduce para que se restituya 'lo excesivamente donado' y no la especie donada, porque bien puede ocurrir que el exceso referido sea una parte del valor de la cosa donada"49. Finalmente habrá que hacer presente que este problema se presentará si lo donado fue una especie o cuerpo cierto, porque si la donación se hizo en género, la restitución podrá hacerse en bienes de dicha naturaleza, y si la donación se hizo en dinero, no cabe duda de que la restitución se realizará en valor.

La misma conclusión se puede obtener del derecho ecuatoriano. En el derecho civil colombiano, la respuesta también será similar a la chilena. Así, Carrizosa indica:

La acción de los legitimarios contra los extraños se dirige a que restituyan lo indebidamente donado, para con tal valor completar el pago de las asignaciones forzosas. El Código dice que entonces las donaciones son rescindibles (art. I482), pero el término está mal usado, porque no se trata de una nulidad relativa que las afecte, sino que se cumplió la condición resolutoria a que estaban ligadas, cual era la de que, al morir el causante, no excedieran de lo que podía disponer libremente. Más propio hubiera sido decir resolubles. Y los legitimarios, en el ejercicio de su acción, deben proceder contra los donatarios en orden inverso al de las fechas de las donaciones, y sin que la insolvencia de unos perjudique a los otros (art. I 245). Esta acción para la restitución de las liberalidades excesivas tiene igual naturaleza que la concedida por el derecho romano, en constituciones posteriores a Alejandro Severo, que se llamó querela inofficiosae donationis y que

47 Para nosotros no es tan claro que el código civil chileno haya recepcionado la legítima como pars hereditatis. Para un estudio sobre la naturaleza jurídica de la legítima en nuestro código civil, cfr. Barría, Asignaciones forzosas, cit., 57-77.

48 Domínguez y Domínguez, Derecho sucesorio, cit., t. II, IO49.

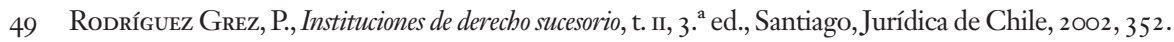


también producía la reducción de las donaciones que habían vulnerado la portio legitima, comenzando por las de fecha más reciente ${ }^{\circ}$.

Pero la tendencia actual en el derecho comparado, que se plasma en la codificación contemporánea, es avanzar a la restitución en valor. Es así como el código civil italiano de 1942 , partiendo como principio de una restitución en especie, consagra la restitución en valor cuando lo donado es un inmueble. Así, el donatario mantiene la propiedad del inmueble, pero debe restituir el exceso en metálico, si el excedente supera la cuarta parte de la porción disponible, según se extrae del artículo 560 c.c. ${ }^{\text {I }}$. Exactamente la misma regla se encuentra en el artículo I073 inciso 2. ${ }^{\circ}$ c.c. de Bolivia.

Por su parte, el código civil de Venezuela tiene una regla especial sobre reducciones de donaciones, en su artículo I468, pero que por aplicación de su inciso final se remite a las reglas de los artículos 888 y siguientes, para la reducción de las disposiciones testamentarias, dentro de las cuales encontramos regla idéntica a la del código civil italiano del artículo 560 citado, especialmente el artículo 893 inciso 2. ${ }^{\circ}$, que establece: "Cuando el legado sujeto a reducción consista en una finca que no admita cómoda división, tendrá derecho a la finca el legatario, si la reducción no absorbe la mitad del valor de dicha finca, y en caso contrario, tendrán este derecho los herederos forzosos, pero aquél y éstos deberán abonarse sus respectivos haberes en dinero". Por lo tanto, al donatario se aplica la misma regla que al legatario. Luego, en el caso de que el inmueble no admita división, como indica Domínguez,

... pueden suceder dos cosas: o bien la reducción no absorbe la mitad del valor del inmueble o bien traspasa esa mitad. Si tiene lugar lo primero, el legatario puede retener el inmueble legado pagando en dinero el excedente, podrá hacer lo mismo el legitimario haciendo al legatario el pago del exceso. Por ejemplo, el testador ha legado una casa de veinte (20) bolívares y como la cuota disponible ha traspasado en ocho (8) bolívares, el legado queda reducido a doce ( ( 2 ) bolívares. El legatario tendrá derecho a la casa, abonando los 8 Bs. Si ocurre lo contrario, esto es, que la porción disponible se hubiese traspasado en I 2 Bs., con lo cual el legado se reduciría a 8 Bs., el legitimario tendría sobre la cosa igual derecho de tomarla para sí, con la obligación de abonar al legatario el excedente de 8 Bs. ${ }^{52}$.

La misma regla se encuentra en el artículo i968, regla primera del código civil de Brasil.

50 Carrizosa, Las sucesiones, cit., 426-427.

5 I Lupi, L., "Della reintegrazione della quota riservata ai legittimari", en Balestra y Di Marzio (coords.), Successioni e donazioni, cit., 737-739.

52 Domínguez Guillén, Manual, cit., 456. 
El nuevo código civil de Argentina expresamente reconoce la restitución en valor. Así, su artículo 2386 indica: "La donación hecha a un descendiente o al cónyuge cuyo valor excede la suma de la porción disponible más la porción legítima del donatario, aunque haya dispensa de colación o mejora, está sujeta a reducción por el valor del exceso". Y en cuanto a los efectos de esa reducción, el inciso $3 .^{\circ} \mathrm{del}$ artículo 2454 conduce a la misma conclusión, al indicar que "el donatario puede impedir la resolución entregando al legitimario la suma de dinero necesaria para completar el valor de su porción legítima". Con ello se pone término a la discusión que sobre el particular se daba bajo la vigencia del antiguo código civil, sobre si la restitución de lo excesivamente donado debía hacerse en especie o bien en valor ${ }^{53}$.

En Uruguay, la restitución también se hace en valor, con base en diversas disposiciones. Como indica Irureta: "Nuestro Código (siguiendo la doctrina establecida por G. Goyena, en sus arts. 877, 878, 89 I, 648, 97 I) descarta evidente-

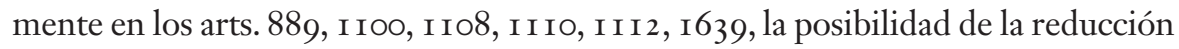
en especie de las donaciones excesivas" 54 . Y más adelante señala:

Esta característica de la reducción en valor de las donaciones, permite desde luego enfocar desde un punto de vista especial, notablemente distinto del que corresponde a la doctrina francesa, la naturaleza del derecho de los legitimarios. Aunque en principio se les reconozca cierta vocación en los bienes mismos, salta a la vista que ese principio sufre excepción en el caso de la donación entre vivos. Un padre puede eludir aquel derecho, donando lo más substancial de sus bienes, incluso, por ejemplo, con reserva de usufructo. La acción de reducción ejercida por los legitimarios sólo debería permitirles, en estricto derecho, percibir sus legítimas en dinero ajeno a la sucesión, o producto de la venta forzada de los mismos bienes 55 .

En el mismo sentido se manifiesta $\mathrm{Vaz}^{5}$. En Paraguay, de acuerdo a lo preceptuado en el artículo 2606 c.c., se ha entendido que también contiene un sistema de restitución en valor. Como indica Köhn: "La doctrina expuesta por Bibiloni, y

53 La discusión se daba por lo que se establecía en el artículo 3955 que establecía: "La acción de reivindicación que compete al heredero legítimo, contra los terceros adquirentes de inmuebles comprendidos en una donación, sujeta a reducción por comprender parte de la legítima del heredero, no es prescriptible sino desde la muerte del donante”. Borda, Manual de sucesiones, cit., 292-293, indicaba que la restitución debe hacerse en especie y así entonces se respetaría la integridad de la legítima. De distinta opinión Zannoni, E., Derecho civil. Derecho de las sucesiones, t. II, Buenos Aires, Astrea, 2008, I99, quien estimaba que el exceso se puede restituir en valor, en virtud del principio de la "conversión del negocio jurídico" ineficaz en razón de su resolución. Así, indicaba: "Se trata, ni más ni menos, de la conversión legal que permite atribuir eficacia al resultado negocial -transmisión del dominio de la cosa donada-, adecuando o compatibilizando ese resultado a un negocio distinto que tiene por fin práctico idéntico resultado”.

Irureta, Curso, cit., 59 .

55 Ibíd., 6o.

56 Vaz Ferreira, E., Tratado de las sucesiones, t. II, Montevideo, Fundación de Cultura Universitaria, I98I, 4I 6-420. 
a la cual se adscribe el art. 2606 del Código Civil, sostiene que lo que se reintegra no es el valor total de la donación o legado por el cual se ha planteado la acción de reducción sino solamente el valor que ha excedido la legítima disponible" 57. En Perú, por su parte, el artículo i645 c.c. dispone: "Si las donaciones exceden la porción disponible de la herencia, se suprimen o reducen en cuanto al exceso las de fecha más reciente, o a prorrata, si fueran de la misma fecha”. Con ello, en principio, según la doctrina, se establece una restitución en especie y excepcionalmente en valor. Así, Fernández indica:

La acción de reducción, como hemos señalado, es una acción personal, en consecuencia, no puede dirigirse contra cualquier donatario, sino solo en contra de aquel beneficiario cuya donación de fecha más reciente resulte inoficiosa. Empero, si este no puede devolver los bienes que recibió en exceso, creemos que, por excepción, la insolvencia deberá ser soportada por las donaciones de fecha anterior y de acuerdo al orden de reducción establecido en el artículo i645 de nuestro Código Civil; en caso de no ser posible lo anterior, el valor de la insolvencia será detraído de la masa hereditaria. En ambos casos, nacerá un derecho de crédito contra el donatario insolvente $5^{8}$.

Finalmente, no se puede dejar de mencionar el código civil francés, que desde su dictación concibió la legítima como pars hereditatis, lo que traía como consecuencia que la restitución debía hacerse in natura. El fundamento radicaba en proteger el patrimonio familiar, y además en establecer la igualdad entre los legitimarios en el momento de la partición. Pero presentaba el inconveniente de que en el momento de proceder a la restitución de los bienes estos podían haber perdido valor económico, con lo que se terminaba perjudicando a los legitimarios $^{59}$. Es por ello que ya en el año i97 I, por Ley de 3 de julio, se estableció la restitución en valor, manteniendo para algunos casos la restitución in natura ${ }^{60}$. Pero, sin duda, es la Ley $2006-728$, de 23 de junio de 2006 , la que vino a modificar de forma relevante la restitución de lo excesivamente donado, ya que en el nuevo artículo 924 se estableció que, sea que se haga una donación a otro legitimario o bien a un tercero, la restitución se hará en valor.

Se podría indicar que varía la naturaleza de la legítima, terminando con la pars hereditatis, pero, como indica Brenner,

Köнn, La legítima, cit., 97-98.

$5^{8}$ Fernández, Manual, cit., 92.

59 Sobre este tema cfr., por todos, Vialleton, H., "Les legs faits aux réservataires et l'attribution de la réserve", Revue trimestrielle de droit civil, n. ${ }^{3}$ 39, I94I, I-39. Es de indicar también que a los asignatarios, que nosotros llamamos "legitimarios", en Francia se les denomina "reservatarios".

6o Cfr., por todos, Ponsard, A., "La loi du 3 juillet I97 I sur le rapport à succession, la réduction pour atteinte à la reserve et les partages d'ascendants", Recueil Dalloz Sirey, I973, I-37. 
... esta innovación, que debilita pero no condena la idea de que la sucesión es pars hereditatis, es muy favorable para la seguridad de las transacciones (ya que el tercero adquirente ya no tiene que temer, en principio, un posible cuestionamiento de su título), pero va mucho más allá porque, a partir de ahora, el causante puede llegar a privar a sus descendientes de todos los bienes en especie eligiendo a un tercero legatario universal ${ }^{6 \mathrm{I}}$.

La finalidad de la reforma, en este punto, es netamente económica, ya que mediante este mecanismo el causante podría dejar todo o parte de sus bienes a uno de sus legitimarios o bien a un tercero, y mediante ello mantener, por ejemplo, una empresa familiar o una unidad económica o agrícola.

\section{La legítima no puede ser objeto de modalidades o gravámenes}

Se trata de una de las manifestaciones más claras de protección al legitimario frente a agresiones que puede sufrir su legítima, desde un punto de vista cuantitativo. En efecto, en caso de no existir este principio, el causante perfectamente podría dejar al legitimario su parte en la herencia, a título de legítimas, pero sujeta a alguna modalidad (p. ej., dejando la legítima o bienes hereditarios bajo una condición suspensiva o un plazo) o bien a un gravamen (p ej., constituyendo un usufructo sobre bienes hereditarios), con el objeto de favorecer a un legitimario en desmedro de otro, o bien para beneficiar a un tercero ajeno a la sucesión. Como indican Domínguez Benavente y Domínguez Águila:

La prohibición se explica fácilmente si se recuerda el carácter de la legítima como derecho. La voluntad del testador puede intervenir en la concreción de la legítima; pero no puede llegar hasta impedir a un legitimario llevarla y, de permitirse la imposición de modalidades, el testador podría indirectamente, por medio de ellas, privarle de su porción. Respetando aparentemente la legítima, podría violarla en el fondo, mediante la constitución de algún gravamen, como un usufructo u otro arbitrio semejante. Se trata, en suma, de defender la intangibilidad cuantitativa de la legítima ${ }^{62}$.

En ese sentido, el código civil chileno reguló esta forma de protección expresamente en el artículo I I92, indicando: "La legítima rigorosa no es susceptible de condición, plazo, modo o gravamen alguno”. Esta disposición y principio se

6i Brenner, C., "La reforma de las sucesiones del 23 de junio de 2006. Ley n. ${ }^{\circ}$ 2006-728 de junio de 2006", en AA.vv., Jornadas colombianas. Las transformaciones del derecho civil francés, Bogotá, Universidad Externado de Colombia, 20 Iо, I 2.

62 Domínguez y Domínguez, Derecho sucesorio, cit., 939. En el mismo sentido Elorriaga, Derecho, cit., $46 \mathrm{I}-466$. 
conoce en toda Sudamérica, por lo que sin dudas hay claridad en orden a aceptarlo como una eficaz forma de proteger la legítima, desde aquellos sistemas que siguieron el código de Bello hasta aquellos que tienen su fuente en el derecho español o italiano.

En efecto, el principio está presente en Ecuador y Colombia. Así, el artículo I 2 I 5 c.c. de Ecuador y el artículo I 250 c.c. de Colombia ${ }^{63}$ contienen textualmente la misma regla que nuestro código civil. El código civil de Uruguay comparte el mismo principio, en su artículo 894, que dispone: "La legítima rigorosa no admite gravamen, condición ni sustitución de ninguna especie" 64 . Por su parte, el código civil de Argentina establece como forma de protección a la legítima esta regla, en el artículo 2447: "El testador no puede imponer gravamen ni condición alguna a las porciones legítimas; si lo hace, se tienen por no escritas" ${ }^{5}$.

Bolivia contiene el mismo principio, en su artículo ro66 inciso r. ${ }^{\circ}$, el cual dispone: "Es nula toda disposición testamentaria por la cual se modifica o suprime la legítima de los herederos forzosos, o se imponen cargas o condiciones sobre ella"66. Lo mismo ocurre en el código civil de Venezuela, que estipula en el artículo 883 inciso $2 .^{\circ}$ : "El testador no puede someter la legítima a ninguna carga ni condición" ${ }^{6}$.

Por su parte, el código civil brasileño es particular en este aspecto, careciendo de una regla tan clara como las que hemos citado hasta ahora. Sin embargo, contiene una regla de protección de la legítima que es bastante particular. En efecto, el artículo r 848 dispone: "Salvo si hay justa causa, declarada en el testamento, no puede el testador establecer cláusula de inalienabilidad, impenetrabilidad, e incomunicabilidad, sobre los bienes de la legítima”. Como se puede apreciar, se trata de una regla que en principio reconoce la imposibilidad de gravar o establecer limitaciones sobre la legítima, pero en ciertos casos lo permite, esto es, cuando exista una justa causa, la que en todo caso debe estar declarada en el

63 Sobre esta regla en el derecho colombiano, cfr. Aguado, Derecho, cit., I97-ig8; Álvarez, Sucesiones, cit., I3 I-I32; Carrizosa Pardo, H., Las sucesiones, 4. ${ }^{\text {a }}$ ed., Bogotá, Lerner, I959, 397; Romero, Curso, cit., 209.

64 Ваввот, R., De las sucesiones, Montevideo, Editor Maximiliano García, I 929, 25 I-252; VAz, Tratado, cit., $283-297$.

65 Dicha regla es prácticamente igual a la que se establecía en el antiguo código civil argentino, que en su artículo 3598 disponía: "El testador no puede imponer gravamen o condición alguna a las porciones legítimas declaradas en este Título. Si lo hiciere, se tendrán por no escritas”.

66 Ver Castellanos, Derecho de sucesiones, cit., I 23-I 24.

67 Sin perjuicio de lo anterior, el derecho venezolano contiene una regla especial, que de cierta forma reconoce lo que en el derecho romano se denominaba "cautela sociniana", que se establece en el artículo 885 el cual reza: "Cuando el testador dispone de un usufructo o de una renta vitalicia, cuyo rendimiento exceda el de la porción disponible, los legitimarios pueden optar entre ejecutar esta disposición o abandonar la propiedad de la porción disponible". Cfr. Domínguez Arce, Manual, cit., 428-432; López, Derecho, cit., 225-236. Esta cautela sociniana se reconoce en el Código Civil italiano, en art. 550. Sobre la cautela sociniana en el derecho italiano, cfr. Отtani, "I legittimari", cit., 709-7 г 2. 
testamento $^{68}$. El mismo principio se extrae del artículo 2607 c.c. de Paraguay ${ }^{69}$. En Perú, el artículo 733 c.c. dispone: "El testador no puede privar de la legítima a sus herederos forzosos, sino en los casos expresamente determinados por la ley, ni imponer sobre aquélla gravamen, modalidad, ni sustitución alguna”7.

\section{La prohibición de celebrar pactos sobre sucesión futura}

En algunas legislaciones europeas, con el objeto de aumentar la libertad de disposición o con fines netamente económicos, específicamente para mantener la unidad de establecimientos de comercio, empresas familiares o unidades agrícolas, se ha permitido el establecimiento de ciertos y determinados contratos sobre una sucesión futura. Así, en Alemania son permitidos los pactos de renuncia sobre la legítima futura en el parágrafo 2346 вяв. En Francia, con la citada reforma del año 2006, se establece el pacto mediante el cual un legitimario puede renunciar a la acción de reducción ${ }^{7 \mathrm{I}}$. Y en España también son permitidos tales pactos en algunas legislaciones forales ${ }^{72}$.

En Chile, sin embargo, la prohibición de pactos sobre sucesiones futuras constituye un principio de carácter general, que no se encuentra específicamente regulado en materia de asignaciones forzosas, sino que está incorporado en las reglas generales sobre actos y declaraciones de voluntad, en el libro iv del código civil, especialmente a propósito del objeto como requisito del acto jurídico, y en particular, a propósito de la prohibición de ilicitud. En efecto, el artículo I 445

68 Elias de Queiroga, Curso, cit., 80-8I; Gozzo, D. y S. De Salvo Venosa, Comentários ao código civil brasileiro. Do direito das sucessoes, vol. xvi, Rio de Janeiro, Forense, 2004, 23 I-237.

69 KöHN, La legítima, cit., 67-68.

70 Ferrero, Derecho, cit., 452-453; Olavarría Vivian, J., Comentarios al derecho de sucesiones, Lima, Escolani, 20 io, i i6-i i 7; Taramona, La legítima, cit., 256.

7 I Sobre la reforma al sistema sucesorio francés del año 2006, y en especial sobre dicho pacto de renuncia a la acción de reducción, cfr. Beabrun, M., "Le nouvel ordre public successoral. Réflexions autor des réformes de $200 \mathrm{I}$ et de 2006", en Cachard, O. y X. Henry (coords.), Mélanges en l'bonneur du professeur Gilles Goubeaux, Paris, Dalloz y LGDJ, 2009, I- I6; BaIllon-Wirtz, N., "Que reste-t-il de la prohibition des pactes sur succession future?", Droit de la famille, n. ${ }^{\circ}$ i I, 2006, 8-I 3; CaSey, J., "Commentaire de la réforme du droit des successions (r ère partie)”, Revue Furidique Personnes \& Famille, n. ${ }^{\circ}$ I o, 2006, 6- I I CASEy, J., "Commentaire de la réforme du droit des successions (2. ${ }^{\text {ème }}$ partie)", Revue furidique Personnes \& Famille, n. o I I, 2006, 6- I I ; Casey, J., "Commentaire de la réforme du droit des successions (3. ${ }^{\text {ère }}$ partie)", Revue furidique Personnes \& Famille, n. ${ }^{\circ}$ I 2, 2007, 6-I I; Dauriac, I., "La renonciation anticipé à l'action en réduction", Recueil Dalloz, n. ${ }^{\circ}$ 37, 2574-2 576; Grimaldi, M., "Présentation de la loi du 23 juin 2006 portant réforme des successions et des libéralités", Recueil Dalloz, n. ${ }^{\circ} 37,2006,255$ I-2 555; LE GuIdec, R., "La loi du 23 juin 2006 portant réforme des successions et libéralités", La Semaine furidique, n. ${ }^{\circ}$ 30, 2006, I489-I494; Malaurie, "La réforme des successions et des libéralités", cit., I 7 I9I735; Vigneau, D., "Les nouvelles règles de dévolution successorale", Recueil Dalloz, n. ${ }^{\circ}$ 37, 2006, $2256-2258$.

72 Así p. ej., para Cataluña, cfr. Navas Navarro, S., "Libertad de testar versus libertad de celebrar pactos sucesorios y costes de transacción. Aproximaciones desde el Derecho de sucesiones catalán”, Anuario de Derecho Civil, t. LXIV, 201 I, fasc. I, 4I-74. 
dispone: "Para que una persona se obligue a otra por un acto o declaración de voluntad es necesario: [...] $3 \cdot{ }^{\circ}$ que recaiga sobre un objeto lícito". Por su parte, el artículo I 463 establece: "El derecho de suceder por causa de muerte a una persona viva no puede ser objeto de una donación o contrato, aun cuando intervenga el consentimiento de la misma persona"73. Finalmente, el artículo r682 inciso I. ${ }^{\circ}$ sanciona con nulidad absoluta los actos o contratos que adolezcan de objeto ilícito, indicando que "[l]a nulidad producida por un objeto o causa ilícita [...] son nulidades absolutas"74.

Pero, pese a su regulación general, no se puede desconocer que esta prohibición justamente tiene por objeto la protección de los legitimarios; pues de no existir, el causante podría celebrar contratos con otros legitimarios o con terceros, para perjudicar sus derechos hereditarios futuros. Este principio también es de aplicación general, y es aceptado, en general, en el derecho sudamericano.

Así, en los mismos términos que en el código civil chileno, se prohíben los pactos sobre sucesión futura en el artículo I 479 c.c. ecuatoriano y en el artículo I 520 c.c. colombiano. El código civil peruano, en su artículo 678 dispone: "No hay aceptación ni renuncia de herencia futura". También el artículo 888 c.c. de Uruguay establece el mismo principio, al señalar: "Toda renuncia o transacción sobre la legítima futura entre aquellos que la deben y sus herederos forzosos, es nula"75. Expresamente se establece la misma prohibición en el artículo 426 c.c. de Brasil, al estipularse: "No puede ser objeto de contrato, la herencia de una persona viva". Lo mismo ocurre en el código de Venezuela, que se refiere a estas prohibiciones en los artículos IO22, I I 56 inciso $2 .^{\circ}$ y I $484^{[76]}$.

En el derecho paraguayo la situación es algo más confusa, puesto que el artículo 2605 no da absoluta claridad sobre la prohibición para celebrar contratos en la herencia futura. La disposición indica:

73 Sobre el objeto ilícito en los pactos sobre sucesión futura, cfr. Domínguez Águila, R., Teoría general del negocio jurídico, 2. ${ }^{\text {a }}$ ed., Santiago, Jurídica de Chile, 2012 , I35-I 36; Alessandri Rodríguez, A.; M. Somarriva Undurraga y A. Vodanovic Hacklicka, Tratado de derecho civil. Partes preliminar y general, t. II, Santiago, Ediciones Jurídicas de Santiago, 201 5, 26 I-262.

74 En Chile, la única excepción a este principio está dada por el pacto de no mejorar, que se encuentra regulado en el artículo i 204 c.c. Sobre este pacto cfr., para el derecho chileno, ElorriagA, Derecho, cit., 482-487; Somarriva, Derecho, cit., 430-433; Rodríguez, Instituciones, cit., 366-37 I.

75 Mariño, Código civil, cit., 485-486, con referencia también al artículo I 285 del mismo código, que establece el mismo principio que el código civil chileno, al indicar: "El derecho de suceder por causa de muerte a una persona viva, no puede ser objeto de ningún contrato".

76 Acerca de los pactos sobre sucesión futura en Venezuela, cfr. Barrios Sánchez, P. y Y. SAlas Peley, "Excepciones al principio de prohibición de disposición sobre las sucesiones futuras en las legislaciones venezolana, española y puertorriqueña", trabajo especial de grado para optar al título de Abogado, Universidad Rafael Urdaneta, Maracaibo, 20 I I, I-I 42, disponible en: http://200.35.84.I3 I/portal/bases/marc/texto/350 I-I I-04786.pdf [Consultado el 30 de mayo de 2017$]$. 
Si el causante ha entregado por contrato en plena propiedad, algunos bienes a uno de los herederos forzosos, cuando sea con cargo de una renta vitalicia o con reserva al usufructo, el valor actualizado de los bienes será imputado sobre la porción disponible del testador, y el excedente será traído a la masa de la sucesión. Esta imputación y esta colación no podrán ser demandadas por los herederos forzosos que hubiesen consentido en la enajenación, y en ningún caso, por los que no tengan designada por la ley una porción legítima.

Como lo indica un autor, se trata de una norma bastante criticada, puesto que, "pese a la prohibición de pactar o estipular sobre la herencia futura, pareciera que la norma dispone sobre la misma”, y cita a varios autores que se pronuncian sobre ello ${ }^{77}$.

Un país que merece una mención especial es sin duda Bolivia. En principio, su código civil consagra la prohibición de los pactos sobre una sucesión futura. Así, el artículo roo4 dispone: "Es nulo todo contrato por el cual una persona dispone de su propia sucesión. Es igualmente nulo todo contrato por el cual una persona dispone de los derechos que puede esperar de una sucesión no abierta, o renuncia a ellos"; regla que es idéntica a la del artículo 458 del código italiano. Pero de inmediato, la regla contiene una calificada excepción o regla especial. Así, el artículo roo5 establece: "Es válido el contrato por el cual una persona compromete la parte o porción disponible de su propia sucesión. No teniendo herederos forzosos, podrá disponer por contrato de la totalidad o parte de su propia sucesión”. La interpretación que debe dársele a esa disposición, como indica Villafuerte, es que "claramente permite a toda persona hacer contratos sucesorios de institución o de disposición respecto de la totalidad o parte de su propia sucesión siempre que no tenga herederos forzosos, en cuyo caso sólo podrá hacerlo de la porción disponible" ${ }^{8}$.

Una última referencia diremos sobre lo que ocurre en el derecho argentino, pues el nuevo código establece como principio la prohibición de celebrar actos y contratos sobre una sucesión futura. Así se establece expresamente en el artículo ıого, que indica: "La herencia futura no puede ser objeto de los contratos ni tampoco pueden serlo los derechos hereditarios eventuales sobre objetos particulares". Sin embargo, el mismo artículo, pero en su inciso $2 .^{\circ}$, establece una calificada excepción, permitiendo ciertos y determinados contratos. Así, la citada regla dispone:

Los pactos relativos a una explotación productiva o a participaciones societarias de cualquier tipo, con miras a la conservación de la unidad de la gestión empre-

77 KöHN, La legítima, cit., 59-6r.

78 Villafuerte Claros, A., Los contratos de sucesión futura en el código civil de 1976, La Paz, Juventud, I990, IOI. 
sarial o a la prevención o solución de conflictos, pueden incluir disposiciones referidas a futuros derechos hereditarios y establecer compensaciones en favor de otros legitimarios. Estos pactos son válidos, sean o no parte el futuro causante y su cónyuge, si no afectan la legítima hereditaria, los derechos del cónyuge, ni los derechos de terceros.

Luego, con fines netamente económicos, se acepta la posibilidad de celebrar pactos o contratos sobre sucesión futura, con el objeto de mantener la continuidad de empresas o unidades económicas de las cuales es titular el causante, pero con la única limitación de no perjudicar los derechos de los legitimarios. Es una manifestación evidente del principio de protección cuantitativa de la legítima, pues se protege el derecho que los legitimarios tienen a ella, aunque se pague en bienes distintos, constituyendo entonces una excepción a la intangibilidad cualitativa de la legítima, en el sentido de que mediante estos pactos puede llegar a ocurrir que los legitimarios sean pagados con bienes distintos a los hereditarios, recibiendo por ejemplo un pago en metálico o valor equivalente a sus derechos en la legítima.

\section{La acción de reforma de testamento}

En nuestro derecho civil, la acción de reforma de testamento constituye sin duda el mecanismo de protección más relevante de que dispone el legitimario, habiéndose definido como "aquella de que gozan los legitimarios para que se modifique el testamento en todo lo que a ellos les corresponde por concepto de legítimas y mejoras" 79 . Se regula en los artículos I 2 I 6 y siguientes del código. Así, el artículo I 2 I 6 inciso I. ${ }^{\circ}$ indica que "los legitimarios a quienes el testador no haya dejado lo que por ley les corresponde, tendrán derecho a que se reforme a su favor el testamento". Por su parte, el artículo I220 dispone: "Si el que tiene descendientes, ascendientes o cónyuge dispusiere de cualquiera parte de la cuarta de mejoras a favor de otras personas, tendrán también derecho los legitimarios para que en eso se reforme el testamento, y se les adjudique dicha parte...”. Luego, el objeto principal de esta acción es impugnar el desheredamiento de que fue objeto un legitimario ${ }^{80}$; reclamar la legítima rigorosa o efectiva en su caso ${ }^{8 \mathrm{r}}$; o bien, reclamar de la cuarta de mejoras, según el citado artículo I 220.

79 Elorriaga, Derecho, cit., 56r.

80 Así se extrae expresamente de lo que se indica en el artículo I 2 I 7 inciso $2 . .^{\circ}:$ "El legitimario que ha sido indebidamente desheredado, tendrá, además, derecho para que subsistan las donaciones entre vivos comprendidas en la desheredación".

8I Que también se indica expresamente en el inciso r. ${ }^{\circ}$ del artículo i 2 I 7 que dispone: "En general, lo que por ley corresponde a los legitimarios y lo que tienen derecho a reclamar por la acción de reforma, es su legítima rigorosa, o la efectiva en su caso". 
También es necesario afirmar que en Chile la acción de reforma de testamento no es una acción de nulidad, pues el testamento no adolece de ningún vicio y por lo demás, en principio, el causante tiene libertad de disposición, respetando los derechos de los legitimarios. Luego, si ellos se ven vulnerados en sus derechos, disponen de esta acción de reforma de testamento.

En el derecho comparado sudamericano, esta acción de reforma de testamento no es desconocida. En efecto, es posible encontrarla con ese nombre y con ese objeto en Ecuador ${ }^{82}$, Colombia ${ }^{8}{ }^{8}$ y Uruguay ${ }^{8}$. En Perú hay acción directa para el caso de que un legitimario haya sido injustamente desheredado, a través de la denominada "acción contradictoria de la desheredación", contemplada en el artículo 750 que señala: "El derecho de contradecir la desheredación corresponde al desheredado o a sus sucesores y se extingue a los dos años, contados desde la muerte del testador o desde que el desheredado tiene conocimiento del contenido del testamento". Luego, se trata de una acción similar a nuestra acción de reforma de testamento, pero que está limitada al legitimario desheredado.

Recientemente en Argentina, en su nueva legislación, no se contiene una acción que se denomine de la forma conocida entre nosotros, pero se llega al mismo objetivo con la que se contiene en el artículo $245 \mathrm{I}$, en donde se le denomina "acción de complemento de la legítima", que establece: "El legitimario a quien el testador le ha dejado, por cualquier título, menos de su porción legítima, sólo puede pedir su complemento". Principio idéntico al establecido en el artículo 3600 del antiguo código civil que disponía: "El heredero forzoso, a quien el testador dejase por cualquier título, menos de la legítima, sólo podrá pedir su complemento" ${ }^{5}$. En el derecho sucesorio paraguayo se siguen los postulados del antiguo derecho argentino ${ }^{86}$. Es por ello que, en este caso, la acción de complemento se combina con la de reducción, según se extrae de los artículos 2600[87] y $2606^{[88]}$. En Venezuela, en caso de afectarse los derechos de los legitimarios, en general se establece la posibilidad de ejercer las acciones de reducción de

82 Regulado en los artículos I 239 y siguientes c.c.

83 Según se extrae de los artículos i 274 y siguientes c.c.

84 Regulado en los artículos roo6 y siguientes c.c. La única diferencia que se presenta con los códigos civiles de Chile, Ecuador y Colombia es que en Uruguay no se puede reclamar de la cuarta de mejoras, precisamente porque en dicho país tal asignación no es conocida ni regulada.

85 Sobre la acción de complemento de la legítima en el derecho civil argentino, cfr. Lo Prete, O., Acciones protectoras de la legítima, Buenos Aires, Hammurabi, 2009, 85-89; Orlandi, O., La legítima y sus modos de protección, 2. ${ }^{\mathrm{a}}$ ed., Buenos Aires, Abeledo Perrot, 2010, I97-207.

86 KöHN, La legítima, cit., 67-69.

87 El cual establece: "Las disposiciones testamentarias y las donaciones entre vivos que menguaren la legítima, se reducirán a la cuota disponible, a solicitud del heredero perjudicado, una vez abierta la sucesión”.

88 Que establece: "Cuando haya que completar la legítima de los herederos forzosos, la acción de reducción podrá ser promovida contra los beneficiarios, a fin de que integren el valor que están obligados a restituir, según las reglas precedentes”. 
las disposiciones testamentarias, contempladas en los artículos 890 a 894 c.c. ${ }^{89}$. Lo mismo ocurre en Brasil, en donde también se permite la reducción de las disposiciones testamentarias que afecten el derecho de los legitimarios, en los artículos i 966 a i968 c.c. $9^{\circ}$.

Diferente es la situación en Bolivia, puesto que, a diferencia de lo que ocurre en las legislaciones citadas, en caso de no dejársele a un legitimario lo que por ley le corresponde, esto acarrea la nulidad de la disposición. Así, el artículo io66 c.c. dispone: "Es nula toda disposición testamentaria por la cual se modifica o suprime la legítima de los herederos forzosos". Por lo tanto, declarada que sea la nulidad de dicha disposición, se restablece el patrimonio del causante, debiéndose dejarse a cada legitimario lo que por ley le corresponde. Se entiende que la legítima en Bolivia es de orden público ${ }^{9 \mathrm{I}}$.

\section{La preterición}

El código civil de Chile reguló la preterición en el artículo I 2 I 8, indicando: "El haber sido pasado en silencio un legitimario, deberá entenderse como una institución de heredero en su legítima". La misma regla es posible encontrarla en el artículo r 24I c.c. de Ecuador ${ }^{22}$, en el artículo i 276 c.c. colombiano ${ }^{93}$ y en el artículo roo8 c.c. de Uruguay ${ }^{94}$, o en similares términos en el artículo 268 I c.c. de Paraguay. A diferencia de lo que ocurre con la acción de reforma de testamento, acá el legitimario fue simplemente olvidado o silenciado en el testamento del causante. Pero ello no origina la nulidad del testamento, pues no adolece de vicio alguno. Esto es distinto de lo que ocurre en otros ordenamientos. Así, el artículo 8 I 4 c.c. español contiene dos casos de preterición, uno de los cuales conduce a la nulidad del testamento, que es la denominada "preterición errónea"95. En Sudamérica, contempla la nulidad del testamento en caso de preterición el artículo r 252 c.c. de Bolivia que establece: "La división en la que el testador no

89 López, Derecho, cit., 266-273.

90 Días, Manual, cit., 289.

9i Castellanos, Derecho, cit., I23-I 24.

92 Sobre la preterición en el derecho ecuatoriano, cfr. Bossano, Manual, cit., Io4; Carrión EgUIguren, E., Compendio de derecho sucesorio, Quito, Pontificia Universidad Católica de Ecuador, I99 I, I36-i 37; Orbe, H., Derecho de sucesión, t. III, Quito, Imprenta Editorial, I977, 39-4I.

93 En el derecho colombiano, sobre la preterición, cfr.: Aguado, Derecho, cit., 2 I 5-2 I 6; Cardona, Tratado, cit., 224-225; Carrizosa, Las sucesiones, cit., 444-445; Romero, Curso, cit., 226; Sú́rez, Derecho, cit., 346-347.

94 VAz, Tratado, cit., 366-373.

95 Torres García, T. y A. Domínguez Luelmo, "La legítima en el código civil”, en Torres García, T. (coord.), Tratado de legítimas, Barcelona, Atelier, $2012,63-64$. 
ha comprendido alguno de los herederos legitimarios o instituidos, es nula". Ello no hace más que repetir lo que se establece en el artículo 735 c.c. italiano ${ }^{6}$.

Por su parte, el nuevo Código Civil y Comercial de la Nación Argentina establece en su artículo 2450: "El legitimario preterido tiene acción para que se le entregue su porción legítima, a título de heredero de cuota. También la tiene el legitimario cuando el difunto no deja bienes pero ha efectuado donaciones"; denominándola "acción de entrega de legítima".

$\mathrm{Al}$ haber sido preterido el legitimario, la ley suple ese silencio del causante. Es por ello que, como dice la norma pertinente del código chileno, al legitimario se le considera como una "institución de heredero en su legítima". Así entonces, en su calidad de heredero, va a poder ejercer todos los derechos y acciones que le corresponden. Por esta razón, la acción que tendrá que ejercer el legitimario preterido es la acción de petición de herencia ${ }^{97}$, no la acción de reforma de testamento ${ }^{9}$. En Venezuela y Brasil no se reguló en forma expresa la preterición, pero se ha estimado que derechamente dichos legitimarios perjudicados debieran ejercer la acción de reducción, en el primer caso, y la acción de petición de herencial, en el segundo. Así, los artículos i 824 y siguientes del código de Brasil regulan en forma expresa la acción de petición de herencia.

Finalmente, una situación particular se advierte en Perú. La preterición se regula en el artículo 806, el cual dispone: "La preterición de uno o más herederos forzosos, invalida la institución de herederos en cuanto resulte afectada la legítima que corresponde a los preteridos. Luego de haber sido pagada ésta, la porción disponible pertenece a quienes hubieren sido instituidos indebidamente herederos, cuya condición legal es la de legatarios". Por su parte, el artículo 865 indica: "Es nula la partición hecha con preterición de algún sucesor. La pretensión es imprescriptible y se tramita como proceso de conocimiento". Ello ha llevado a la doctrina a señalar que en este caso estamos en presencia de la caducidad del testamento, lo que se traduce en la nulidad del mismo99.

\section{Conclusiones}

Del repaso general al sistema de protección sucesoria de las asignaciones forzosas, y en especial de la legítima, en el derecho chileno, así como de la revisión de la situación en el derecho sudamericano, es posible extraer algunas precisas consecuencias:

96 En el derecho italiano, Colangeli, D., "La divisione testamentaria", en Balestra y Di Marzio (coords.), Successioni e donazioni, cit., I427-1428.

97 Somarriva, Derecho, cit., t. II, 5 I 5; Elorriaga, Derecho, cit., 573-574.

98 Lo cual en todo caso no constituye una opinión unánime en la doctrina. Así, cfr. Rodríguez, Instituciones, cit., vol. II, 55, estima que la acción del preterido es la acción de reforma de testamento.

99 Taramona, Derecho, cit., 253-254. 
I. En todos los países de Sudamérica es posible identificar la legítima, como un derecho que la ley concede a ciertas personas, llamados legitimarios.

2. En Chile y en todas las legislaciones se acepta el principio de intangibilidad cuantitativa de la legítima, en el sentido de que los legitimarios tienen un derecho a su legítima desde el punto de vista del quántum.

3. Los mecanismos directos de protección de la legítima en Chile se regulan en general en materia de asignaciones forzosas, salvo los pactos sobre sucesión futura, que se reglan dentro de las normas generales sobre actos y declaraciones de voluntad. Lo mismo ocurre con los países que siguieron el código civil chileno en materia sucesoria, como Ecuador y Colombia.

4. El resto de los ordenamientos estudiados disponen de reglas protectoras que no se establecen necesariamente en materia de legítimas. Así, en algunos países los sistemas de colación e imputación se encuentran en materia de partición de bienes. Por su parte, las acciones de reducción de donaciones excesivas se encuentran en materia de donación.

5. Quizás un punto de diferencia entre los sistemas analizados es la forma en que se debe realizar la restitución en caso de que se ejerza la acción de inoficiosa donación o de reducción de donaciones o liberalidades, en su caso, en el sentido de si debe realizarse in natura o bien en valor, con una fuerte tendencia hacia este último mecanismo. Pero esto se vincula más con la intangibilidad cualitativa que con la intangibilidad cuantitativa de la legítima.

6. En general, en caso de que no respete la legítima de esos asignatarios, no se genera la nulidad del testamento, sino que se entregan mecanismos para restablecer el patrimonio del causante, con el objeto de proteger a los legitimarios y asegurarles la cuota que por ley les corresponde. La excepción la podemos encontrar en Bolivia, en donde, que en caso de que el testador prive a su legitimario de la legítima, o de que dicho legitimario sea preterido, se genera la nulidad del testamento.

7. En general, con más o menos matices, con los mismos o diversos nombres, con regulación especial o general, lo cierto es que en todos los países de Sudamérica la legítima se protege desde un punto de vista cuantitativo, a través de los mismos mecanismos, como tuvimos la forma de revisar.

\section{Referencias}

Aguado Montaño, E. M., Derecho de sucesiones, Bogotá, Leyer, 2000.

Aguilar Llanos, B., Derecho de sucesiones, Lima, Ediciones Legales, 20 io.

Albaladejo García, M., La mejora, Madrid, Servicio de Estudios del Colegio de Registradores, 2003.

Alessandri Rodríguez, A.; M. Somarriva Undurraga y A. Vodanovic Hacklicka, Tratado de derecho civil. Partes preliminar y general, t. II, Santiago, Ediciones Jurídicas de Santiago, 2015 . 
Álvarez Rico, H., Apuntes de derecho común. Sucesiones, Bogotá, Universidad Católica de Colombia, 1986.

Baillon-Wirtz, N., "Que reste-t-il de la prohibition des pactes sur succession future?", Droit de la famille, n. $^{\circ}$ I I, 2006, 8-I3.

Balestra, L.; M. Di Marzio, A. Gianola, V. Lenoci y S. Matteini Chiari, "Successioni e donazioni”, en Cendon, P. (dir.), Trattario di diritto civile, Milano, Giuffré, 2015, 224-227.

Barbot, R., De las sucesiones, Montevideo, Maximiliano García, I929.

Barría Paredes, M., "Panorama normativo de los sistemas sucesorios en Latinoamérica”, en Barría, M.; B. Caprile, J. L. Díez, C. Domínguez, C. Pizarro y M. Tapia (coords.), Estudios de derecho privado. Homenaje al profesor Ramón Dominguez Águila, Santiago, Thomson Reuters, 2015.

Barrios Sánchez, P. y Y. Salas Peley, "Excepciones al principio de prohibición de disposición sobre las sucesiones futuras en las legislaciones venezolana, española y puertorriqueña", trabajo especial de grado para optar al título de Abogado, Universidad Rafael Urdaneta, Maracaibo, 20 I I, I-I42, disponible en: http://200.35.84. I3 I/portal/bases/marc/texto/350 I-I I-04786.pdf [consultado al 30 de mayo de 20I 7 ].

BAZÁn DÁvila, R., "De la colación”, memoria de prueba para optar al grado de Licenciado en Ciencias Jurídicas, Santiago, Universidad de Chile, I946.

Beabrun, M., "Le nouvel ordre public successoral. Réflexions autor des réformes de $200 \mathrm{I}$ et de 2006", en Cachard, O. y X. Henry (coords.), Mélanges en l'honneur du professeur Gilles Goubeaux, Paris, Dalloz y LGDJ, 2009, I-I6.

Bello López, A., Código civil de la República de Chile, Caracas, Ministerio de Educación, I955.

Borda, G., Manual de sucesiones, I4. . ed., Buenos Aires, Lexis Nexis y Abeledo Perrot, 2004 .

Bossano, G., Manual de derecho sucesorio, 2. ${ }^{\mathrm{a}}$ parte, Quito, Voluntad, I983.

Brenner, C., "La reforma de las sucesiones del 23 de junio de 2006. Ley n. ${ }^{\text {o } 2006-728}$ de junio de 2006", en AA.vv., fornadas colombianas. Las transformaciones del derecho civil francés, Bogotá, Universidad Externado de Colombia, 20 Io.

Campagnolo, R., Le successioni mortis causa, Torino, Utet, $20 \mathrm{I}$ I.

Capozzi, G., Successioni e donazioni, t. I, 4. ${ }^{\text {a }}$ ed., Milano, Giuffré, 2015.

Cardona Hernández, G., Tratado de sucesiones, Bogotá, Doctrina y Ley, 2004.

Carrión Eguiguren, E., Compendio de derecho sucesorio, Quito, Pontificia Universidad Católica de Ecuador, I99I.

Carrizosa Pardo, H., Las sucesiones, 4 . $^{\text {a }}$ ed., Bogotá, Lerner, I 959.

Carrizosa Pardo, H., Las sucesiones, Bogotá, Lerner, I977.

Casey, J., "Commentaire de la réforme du droit des successions (i. ${ }^{\text {ère }}$ partie)", Revue furidique Personnes \& Famille, n. ${ }^{\circ}$ Io, 2006, 6-I I.

Casey, J., "Commentaire de la réforme du droit des successions (2. ${ }^{\text {ème }}$ partie)", Revue Furidique Personnes \& Famille, n. ${ }^{\circ}$ I I, 2006, 6-I I. 
Casey, J., "Commentaire de la réforme du droit des successions ( $3 .{ }^{\text {ème }}$ partie)", Revue Furidique Personnes \&o Famille, n. ${ }^{\circ}$ I 2, 2007, 6- I I.

Castellanos Trigo, G., Derecho de sucesiones conforme al código civil boliviano, Sucre, Talleres Gráficos Gaviota del Sur, 2007.

Catala, P., "La loi du 23 du juin 2006 et les coonnes du temple", Droit de la famille, n. $^{\text {o }}$ I I, 2006.

Colangeli, D., "La collazione”, en Balestra, L. y M. Di Marzio (coords.), Successioni e donazioni, Padova, Cedam, 2014, I 495-I 573.

Colangeli, D., "La divisione testamentaria”, en Balestra, L. y M. Di Marzio (coords.), Successioni e donazioni, Padova, Cedam, 2014, I427-I428.

Corte Constitucional de Colombia, Sentencia C-64i/oo del 3 i de mayo de 2000 , disponible en: http://www.corteconstitucional.gov.co/relatoria/200o/C-64I-oo.htm [consultada al 30 de mayo de 2017].

Dauriac, I., "La renonciation anticipé à l'action en réduction”, Recueil Dalloz, n. ${ }^{\circ} 37$, $2574-2576$.

De Miranda, P., Tratado de direito privado. Parte especial. Direito das sucessoes, t. Lv, Sao Paulo, Revista dos Tribunais, 2012.

Días, M. B., Manual das sucessoes, 4. . ed., Sao Paulo, Revista dos Tribunais, 20 I6.

Domínguez Águila, R., Teoría general del negocio jurídico, 2. a ed., Santiago, Jurídica de Chile, 2012.

Domínguez Benavente, R. y R. Domínguez Águila, Derecho sucesorio, t. il, $3 \cdot{ }^{a}$ ed., Santiago, Jurídica de Chile, 20 I I.

Domínguez Guillén, M. C., Manual de derecho sucesorio, Caracas, Texto, 2 o o.

Elías de Queiroga, A., Curso de direito civil. Direito das sucessoes, Sao Paulo, Renovar, 2005.

Elorriaga de Bonis, F., Derecho sucesorio, 3. ${ }^{a}$ ed., Santiago, Thomson Reuters, 2015.

Espinel Blanco, V., Derecho sucesoral, Bogotá, Temis, I984.

Fernández Arce, C., Manual de derecho sucesorio, Lima, Pontificia Universidad Católica del Perú, 20I4.

Ferrero, Augusto, Derecho de sucesiones, 4 . $^{\text {a }}$ ed., Lima, Cultural Cuzco, I993.

Gomes, O., Sucessoes, I 2. ${ }^{a}$ ed., Rio de Janeiro, Forense, 2004.

Gozzo, D. y S. De Salvo Venosa, Comentários ao código civil brasileiro. Do direito das sucessoes, vol. xvi, Rio de Janeiro, Forense, 2004.

Grimaldi, M., "Présentation de la loi du 23 juin 2006 portant réforme des successions et des libéralités", Recueil Dalloz, n. ${ }^{\circ}$ 37, 2006, $255^{\text {I-2 } 555 .}$

Guzmán Brito, A., La codificación civil en Iberoamérica. Siglos XIX y XX, Santiago, Jurídica de Chile, 2000.

Inochea Rojas, J., Manual práctico de derecho sucesorio, Cochabamba, Alexander, 20 Io.

Irureta Goyena, J., Curso de sucesiones, t. v, Montevideo, Centro de Estudiantes de Derecho, I966. 
Köhn Gallardo, M. A., La legítima hereditaria, Asunción, Intercontinental, 2008.

Le Guidec, Raymond, "La loi du 23 juin 2006 portant réforme des successions et libéralités", La Semaine Furidique, n. ${ }^{\circ}$ 30, 2006, I489-I 494.

Lo Prete, O., Acciones protectoras de la legítima, Buenos Aires, Hammurabi, 2009.

Lôво, P., Direito Civil. Sucessoes, 2. ${ }^{a}$ ed., Sao Paulo, Saravia, 20 I4.

López Herrera, F., Derecho de sucesiones, t. I, 4. ${ }^{a}$ ed., Caracas, Universidad Católica Andrés Bello, 2008.

Lupi, L., "Della reintegrazione della quota riservata ai legitimari”, en BALESTra, L., y M. Di Marzio (coords.), Successioni e donazioni, Padova, Cedam, 2014, 737-739.

Lupi, L., "I legittimari”, en Balestra, L., y M. Di Marzio (coords.), Successioni e donazioni, Padova, Cedam, 2014, 728-762.

Maffía, J., Tratado de las sucesiones, t. I, 2. . ed., Buenos Aires, Abeledo Perrot, 20 io.

Malaurie, P., "La réforme des successions et des libéralités", Répertoire du Notariat Defrénois, n. ${ }^{\circ} 22,2006$, I 7 19-1 735 .

Mariño López, A., Código civil de la República Oriental del Uruguay. Comentado, anotado y concordado, Montevideo, La Ley, 2009.

Navas Navarro, S., "Libertad de testar versus libertad de celebrar pactos sucesorios y costes de transacción. Aproximaciones desde el derecho de sucesiones catalán", Anuario de Derecho Civil, t. LXIV, 20 I I, fasc. I, 4I-74.

Olavarría Vivian, J., Comentarios al derecho de sucesiones, Lima, Escolani, 20 io.

Orbe, H., Derecho de sucesión, t. II, Quito, Imprenta Editorial, I977.

Orbe, H., Derecho de sucesión, t. III, Quito, Imprenta Editorial, I977.

Orlandi, O., La legítima y sus modos de protección, 2. ${ }^{\text {a }}$ ed., Buenos Aires, Abeledo Perrot, 2010.

Ottani Sconza, V., "I legittimari”, en Balestra, L. y M. Di Marzio (coords.), Successioni e donazioni, Padova, Cedam, 2014, 704-709.

Peñailillo Arévalo, D., "El principio de igualdad en el derecho sucesorio", Revista de Derecho Universidad de Concepción, n. ${ }^{\circ}$ I43, 1968, 62-63.

Pérez Lasala, J. L., Curso de derecho sucesorio, 2. a ed., Buenos Aires, LexisNexis, 2007.

Ponsard, A., "La loi du 3 juillet I 97 I sur le rapport à succession, la réduction pour atteinte à la reserve et les partages d'ascendants", Recueil Dalloz Sirey, I973, I-37.

Ramírez Fuentes, R., Las sucesiones, Bogotá, Pequeño Foro, 1983.

Ramos Pazos, R., Sucesión por causa de muerte, Santiago, Jurídica de Chile, 2008.

Real Pérez, A., Intangibilidad cualitativa de la legítima, Madrid, Civitas, I 988.

Ribeiro de Magalhaes, R., Direito das sucessoes no novo código civil brasileiro, 2. a ed., Sao Paulo, Juarez de Oliveira, 2004.

Rodríguez Grez, P., Instituciones de derecho sucesorio, t. II, 3. ${ }^{a}$ ed., Santiago, Jurídica de Chile, 2002. 
Romero Cifuentes, A., Curso de sucesiones, 2. . ed., Bogotá, Ediciones Librería del Profesional, 1983 .

Somarriva Undurraga, M., Derecho sucesorio, 7. ${ }^{a}$ ed., versión de R. Abeliuk, Santiago, Jurídica de Chile, 2007.

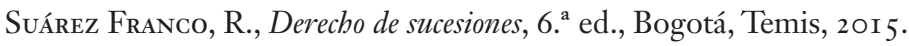

Taramona Hernández, J. R., Derecho de sucesiones, Lima, Huallaga, I 999.

Torres García, T. y A. Domínguez Luelmo, "La legítima en el código civil”, en Torres García, T. (coord.), Tratado de legítimas, Barcelona, Atelier, 2012.

Vaz Ferreira, E., Tratado de las sucesiones, t. iI, Montevideo, Fundación de Cultura Universitaria, I98I.

Velásquez Londoño, R., Derecho de herencia, Medellín, Señal Editora, I 988.

VÉLEz, F., Estudio sobre el derecho civil colombiano, t. iv, París, Imprenta París-América, I 929.

Vialleton, H., "Les legs faits aux réservataires et l'attribution de la réserve", Revue Trimestrielle de droit civil, n. $^{\circ}$ 39, I94I, I-39.

Vigneau, D., "Les nouvelles règles de dévolution successorale", Recueil Dalloz, n. ${ }^{\circ} 37$, $2006,2256-225^{8}$.

Villafuerte Claros, A., Los contratos de sucesión futura en el código civil de 1976, La Paz, Juventud, I990.

Zannoni, E., Derecho civil. Derecho de las sucesiones, t. II, Buenos Aires, Astrea, 2008. 